\title{
Application of Glyceroglycolipids, Photosynthetic Pigments and Extracts of Brown Algae for Suppression ROS
}

\author{
Natalia Gerasimenko, Ekaterina Menchinskaya, Andrey Esipov, Dmitry Aminin, \\ Stepan Logvinov, Eugene Pislyagin \\ G. B. Elakov Pacific Institute of Bioorganic Chemistry, Far Eastern Branch, Russian Academy of Sciences, \\ Vladivostok, Russia \\ Email: gerana@piboc.dvo.ru,nigeras.516@gmail.com
}

Received 19 May 2016; accepted 1 July 2016; published 5 July 2016

Copyright (C) 2016 by authors and Scientific Research Publishing Inc.

This work is licensed under the Creative Commons Attribution International License (CC BY). http://creativecommons.org/licenses/by/4.0/

c) (7) Open Access

\begin{abstract}
Lipid-rich extracts were obtained from brown algae Saccharina cichorioides, Costaria costata, Chorda filum, Eularia fistulosa, Dictyopteris divaricata, Dictyosiphon chordaria, Silvetia babingtonii, and Fucus evanescens that were collected in Peter the Great Gulf of the Sea of Japan. The ability of algal extracts and glyceroglycolipids (GLs) monogalactosyldiacylglycerols (MGDG), digalactosyldiacylglycerols (DGDG), and sulfoquinovosyldiacylglycerols (SQDG) and carotenoid fucoxanthin to suppression of reactive oxygen species (ROS) in lipopolysaccharide (LPS)-stimulated RAW 264.7 macrophage cells, studied.The results showed that algae extracts could suppress ROS. However, extracts of $D$. divaricata, $D$. chordaria, $C$. filum, S. babingtonii, and $F$. evanescens had a higher degree of suppression of ROS. Extracts of $S$. cichorioides and D. divaricata showed the dependence of their activity from the month of collecting these algae. The GLs and fucoxanthin were isolated from extracts of using column chromatography with silica gel and their ROS-inhibitory activity was investigated too. The fatty acids (FAs) composition of lipids was determined by GC and GC/MS. It has been found that MGDG and DGDG stronger than SGDG inhibited the ROS and the degree of their activity depended on the species of algae, the month of collection, the amount of PUFA, the ratio of $\mathbf{n}$ 3 and $n-6$ PUFA in GLs. Fucoxanthin has shown a high degree of suppression of ROS. This preliminary study has shown the prospect of a deeper study of the suppression of ROS with the help of lipids from algae the Sea of Japan.
\end{abstract}

\section{Keywords}

Algae, Glyceroglycolipids, Fucoxanthin, Fatty Acids, Reactive Oxygen Species (ROS) 


\section{Introduction}

Brown algae are widely distributed in cold and in temperate latitudes of Asian and American coasts of Pacific Ocean as well as the coasts of the Russian Far East. Algae have been of great interest as marine food sources. In additionally, they are rich source of bioactive substances with antioxidant [1]-[6], anti-inflammatory [7]-[9], antihypertensive [10], anti-allergic [11] and neuroprotective [12] properties. Reactive oxygen species (ROS) attracts draws many researches. ROS are produce by all aerobic organisms and can easily react with most biological molecules including DNA, proteins, lipids and lipoproteins. This can generate oxidative stress and produce many disorders such as ageing, atherosclerosis, arthritis, diabetes, cataractogenesis, pulmonary dysfunction, muscular dystrophy, ischemia perfusion, tissue damage and neurological disorders, such as Alzheimer's disease [13]. Therefore, there are increased interest in finding functional foods and pharmaceutical product, which prevent oxidative stress [14]. Many studies have reported that seaweeds, which contain antioxidant, have antiinflammatory effect too [15]-[17]. A lot of attention has been concentrated on investigation of algal alcoholic extracts and its fractions, which were prepared from them by different solvents. So, methanol extracts of 17 species of seaweeds were screened for their ability inhibits the total ROS in kidney homogenate. Among them, methanol extract of brown alga Ecklonia stolonifera inhibited 44.3\% the total ROS [18]. Methanol extracts of brown seaweeds Scytosiphon lomentaria, Sargassum nigrifolium and Ishige okamurae shown strong ROS scavenging effect in RAW 264.7 macrophage cells as acetone/dichloromethane extracts of S. lomentaria, S. horneri and Dictyopteris divaricata [19]. Extract of other brown alga S. myriocystum quenched $80 \%$ to $120 \%$ of hydroxyl radical [20]. Strong anti-inflammatory potential of the methanol extract and its fractions of Eisenia bicyclis were detected also [21]. The methanol extract and their ethyl acetate and dichloromethane fractions of Saccharina japonica demonstrated the high inhibition of LPS-induced NO production in RAW 264.7 macrophage cells [22]. Investigation extracts of four species of brown algae Ecklonia radiata, Hormosira banksii, Phyllospora comosa and Myriogloea sciurus shown that nonpolar lipid-rich dichloromethane extracts of these algae had greatest anti-inflammatory activity (via inhibition of nitric oxide), compared with intermediate polarity ethyl acetate extracts and with the lowest activity observed in the polar butanol extracts [23]. Methanol extract and its hexane and chloroform fractions of brown seaweed Spatoglossum schroederi showed anti-inflammatory effect, which may be related to the presence of flavonoids [24]. Phlorotannins [18] [21] [25]-[27], fucosterol [21], pheophorbide and pheophytin $a$ [22] and carotenoid fucoxanthin [28]-[29] inhibited the production of inflammatory mediators also. Apparently, that many structurally diverse substances of algae have ability to anti-inflammatory effect. At the same time, similar information about of algae lipids is extremely small [30]-[34], especially for brown algae [30] [33]. So, recently has been showed, that monogalactosyldiacylglycerols and monoacylglycerol from brown alga Fucus spiralis have strong NO inhibitory activity against LPS-induced NO production in murine RAW264.7 cells [33] and glyceroglycolipid ishigoside of Ishige okamurae is a potential free-radical scavenger against DPPH, hydroxyl, alkyl, and superoxide radicals [30].

Earlier, our studies have shown that lipids and photosynthetic pigments (PSP) of brown algae (Sea of Okhotsk and Sea of Japan) have antimicrobial, hemolytic, and embryotoxic activities [35]-[37] and are promising for further studies. In this work, extracts of eight brown algae and their GLs such as MGDG, DGDG, SQDG and carotenoid fucoxanthin were screened for their capacity to suppress ROS in LPS-stimulated RAW264.7 macrophage cells. Side by side with this was evaluated influence FAs of extracts and GLs on suppression ROS in these cells.

\section{Materials and Methods}

\subsection{Plant Material}

Samples of S. cichorioides (Miybei) C. E. Lane, C. Mayes, Druehl et G.W. Saunders, C. costata (Turner) Saunders, C. filum (Linnaeus) Stackhouse and E. fistulosa (order Laminariales); D. divaricata (Okamura) Okamura (order Dictyotales); D. chordaria Areschoug (order Ectocarpales); S. babingtonii (Harvey) E. A. Serrao, T. O. Cho, S. M. Boo et Brawley and F. evanescens C. Agardh (order Fucales) were collected in Trinity Bay (42 $38^{\prime} \mathrm{N}$ and $\left.131^{\circ} 06^{\prime} \mathrm{E}\right)$ Peter the Great Gulf of the Sea of Japan on Marine Experimental Station. Algal samples were cleaned from sand particles and epiphytes and rinsed in running water. Samples were dried out with filter paper and weighed. Substances extracted of immediately. Algal thalli crushed in blender, mixed carefully. 200 - $300 \mathrm{~g}$ of sample was used for homogenization with $\mathrm{EtOH}(0.5 \mathrm{~L})$ and the mixture of $\mathrm{EtOH} / \mathrm{CHCl}_{3}(1: 1,0.7 \mathrm{~L} \times 2)$. 
Extracts were combined, and distilled water was added to form a biphasic system. Water layer was separated and extract evaporated to dryness and weighed. It was stored in sealed flasks at $-25^{\circ} \mathrm{C}$. Substances content was determined by the gravimetric method and as percentage of the algae wet weight.

\subsection{The Content of Lipids}

GLs content was determined according to the sulfuric-orcinol procedure [38] with slight modification. Briefly, TLC of the GLs carried out on the $12 \times 12 \mathrm{~cm}$ plates covered with silica gel $60_{\mathrm{F} 254}$ (Merck, Germany) using mobile phase $\left(\mathrm{CH}_{3}\right)_{2} \mathrm{CO} / \mathrm{C}_{6} \mathrm{H}_{6} / \mathrm{H}_{2} \mathrm{O}(91: 30: 8, v / v / v)$. Spots corresponding to several classes GLs were scraped off the plate in a tubes and sulfuric-orcinol reagent was added. The test tubes were warmed to $80^{\circ} \mathrm{C}$ for $20 \mathrm{~min}$. After centrifugation, the absorbance was measured at $505 \mathrm{~nm}$. MGDG, DGDG and SQDG were using for constructed of calibration curves. Phospholipids (PL) were quantified based on the content of phosphorus using molybdate reagent [39]. Neutral lipids (NL) were analyzed by TLC on the $12 \times 12 \mathrm{~cm}$ plates covered with silica gel $60_{\text {F254 }}$ in solvent system $\mathrm{C}_{6} \mathrm{H}_{14} /\left(\mathrm{C}_{2} \mathrm{H}_{5}\right)_{2} \mathrm{O} / \mathrm{CH}_{3} \mathrm{COOH}(80: 20: 1, v / v / v)$. The content of TAG was estimated by gas chromatography (GC), using 17:0 FA as an internal standard [40].

\subsection{The Content of Pigments}

The content of carotenoids and chlorophylls were determined after separation extracts on the plates $10 \times 15 \mathrm{~cm}$ with silica gel $60_{\mathrm{F} 254}$ (Merck, Germany) using of mobile phase $\mathrm{C}_{6} \mathrm{H}_{14} /\left(\mathrm{CH}_{3}\right)_{2} \mathrm{CO} /\left(\mathrm{C}_{2} \mathrm{H}_{5}\right)_{2} \mathrm{O}(50: 20: 4, v / v / v)$. Carotenoids were identified by comparison with authentic standards of fucoxanthin and $b$-carotene (Sigma-Aldrich). Major carotenoids and chlorophylls bands were scraped off the plate and eluted with $\mathrm{CHCl}_{3}$. Absorption maxima ( $\lambda$ max, nm) were measured with using the SF 2000 spectrophotometer (Spektr, St. Petersburg, Russia). Quantitative estimates of carotenoids were determined using the following extinction coefficients of E1\% (1 cm path) in ethanol: 2500 for a mixture of pigments at $\lambda \max 450 \mathrm{~nm}$ [41] [42] and 1280 at $\lambda$ max $448 \mathrm{~nm}$ for fucoxanthin [43]. The total chlorophylls content was determined using of E1\% 840 (in acetone) at $\lambda$ max $663 \mathrm{~nm}$ [41].

\subsection{Isolation of GLs and Fucoxanthin}

All extracts of algae were separated with use by one scheme. Extracts (300 - $500 \mathrm{mg}$ ) was suspended in a small volume of n-hexane and applied to the top of a column $(12-15 \times 2.0-2.5 \mathrm{~cm})$ filled with silica gel 40/100 $\mu \mathrm{m}$ (Chemapol, Lachema, Czech Republic) in n-hexane. Neutral lipids and photosynthetic pigments were eluted consequently with n-hexane, $\mathrm{C}_{6} \mathrm{H}_{14} /\left(\mathrm{C}_{2} \mathrm{H}_{5}\right)_{2} \mathrm{O}(95: 5 \rightarrow 50: 50, \mathrm{v} / \mathrm{v})$ and then with $\mathrm{CHCl}_{3}$ (fractions fucoxanthin and free FA). Fractions of fucoxanthin were monitored by TLC using $\mathrm{C}_{6} \mathrm{H}_{14} /\left(\mathrm{CH}_{3}\right)_{2} \mathrm{CO}(70: 30, v / v)$ as mobile phase and standard fucoxanthin (Sigma-Aldrich).GLs were eluted with mixtures of $\mathrm{CHCl}_{3} /\left(\mathrm{CH}_{3}\right)_{2} \mathrm{CO}(90: 10 \rightarrow$ 50:50, $v / v$, fractions $1-3)$. The fractions of GLs were monitored by TLC using solvent system $\left(\mathrm{CH}_{3}\right)_{2} \mathrm{CO} /$ $\mathrm{C}_{6} \mathrm{H}_{6} / \mathrm{H}_{2} \mathrm{O}(91: 30: 8, v / v / v)$ with authentic standards of GLs. In additional $\mathrm{C}_{6} \mathrm{H}_{14} /\left(\mathrm{CH}_{3}\right)_{2} \mathrm{CO}(70: 30, v / v)$ mobile phase and standard chlorophyll $a$ were used. The fractions containing identical substances were combined, dried in vacuum and dissolved in $\mathrm{CHCl}_{3}$. Fractions 1 consisted MGDG and a little of carotenoids and chlorophylls and free fatty acids; fraction 2-DGDG with a little amount of phospholipids and chlorophylls, fractions 3-SQDG with chlorophylls and phospholipids. These fractions were purified again on additional columns of silica gel (5 $6 \times 1.5 \mathrm{~cm})$.Substances were eluted with $\mathrm{CHCl}_{3}$ and $\mathrm{CHCl}_{3} /\left(\mathrm{CH}_{3}\right)_{2} \mathrm{CO}$ as described above. Fractions were collected with a volume of $5 \mathrm{ml}$ and purity of substances monitored by TLC. Fucoxanthin, MGDG, DGDG and SQDG were dried in vacuum and stored at $-25^{\circ} \mathrm{C}$ in sealed flasks before analysis.

\subsection{Fatty Acids Analysis}

Fatty acid methyl esters (FAME) prepared according to the method of Prevot and Mordret [44] with slight modification. Briefly, $2 \mathrm{ml}$-hexane and $0.4 \mathrm{ml} 2 \mathrm{~N} \mathrm{KOH}$ in $\mathrm{MeOH}$ was added to an aliquot of lipids, vortexed for $30 \mathrm{~s}$ and incubated at $50^{\circ} \mathrm{C}$ up to $2 \mathrm{~min}$. Then $0.4 \mathrm{ml} 2 \mathrm{~N} \mathrm{HCl}$ in $\mathrm{MeOH}$ was added to the solution and vortexed up to $3 \mathrm{~min}$ at room temperature. The mixture was left for1-2 min. After that, the upper hexane layer containing FAME was recover and crude FAME were purified by TLC in $\mathrm{C}_{6} \mathrm{H}_{14} / \mathrm{C}_{6} \mathrm{H}_{6}(7: 3, v / v)$ as mobile phase and analyzed by GC using Shimadzu 2010 Plus gas chromathograph (Japan) with a flame ionization detector. Supelcowax 10 column $\left(30 \mathrm{~m} \times 0.25 \mathrm{~mm}\right.$ i.d.; $0.25 \mu \mathrm{m}$ film, Supelco, USA) was used (isotherm, $210^{\circ} \mathrm{C}$; He- 1 
ml/min; He-linear velocity, $40 \mathrm{~cm} / \mathrm{sec}$ ). FAME was identified by equivalent chain length values (ECL) [45]. Pirrolidide derivatives ( $N$-acyl pirrolidides) were used for determination of double bond positions. These derivatives were prepared by direct treatment of FAME with $\mathrm{C}_{4} \mathrm{H}_{9} \mathrm{~N} / \mathrm{CH}_{3} \mathrm{COOH}(10: 1, v / v)$ at $80^{\circ} \mathrm{C}$ for 45 min [46] and purified by TLC in mixture $\mathrm{C}_{6} \mathrm{H}_{14} /\left(\mathrm{C}_{2} \mathrm{H}_{5}\right)_{2} \mathrm{O}(2: 1, v / v)$. The pyrrolidides were analyzed by gas chromatography/mass spectrometry (GC/MS) using Agilent 6890 gas chromathograph with quadrupole mass selective detector (MSD) HP 5973 (ionization energy was $70 \mathrm{eV}$ ) and HP-5ms column (30 m × 0.25 mm i.d.; $0.25 \mu \mathrm{m}$ film, Agilent, USA). Temperature regime was programmed: $205^{\circ} \mathrm{C}-5 \mathrm{~min}, 5^{\circ} \mathrm{C} / \mathrm{min}$ to $240^{\circ} \mathrm{C}, 20^{\circ} \mathrm{C}-30 \mathrm{~min}$; $\mathrm{He}-$ $1.3 \mathrm{ml} / \mathrm{min}$. The solvent delay for pirrolidide derivatives was $3 \mathrm{~min}$.

\subsection{Cell Line}

The murine macrophage Raw 264.7 cell line was obtained from the American Type Culture Collection (Manassas, VA). The cells were cultured in DMEM supplemented with 10\% FBS, $100 \mathrm{U} / \mathrm{ml}$ of penicillin, and 100 $\mu \mathrm{g} / \mathrm{ml}$ of streptomycin (Sigma-Aldrich), at $37^{\circ} \mathrm{C}$ under a humidified $5 \% \mathrm{CO}_{2}$ atmosphere in incubator (MCO18AIC, Sanyo, Japan).

\subsection{Viability Cells}

The cell viability assay was evaluated according to the MTT method [47] with slight modification. Briefly, RAW 264.7 murine macrophages $\left(5 \times 10^{5}\right.$ /well) were seeded in a 96-well microplate and cultured at $37^{\circ} \mathrm{C}$ for 2 h. After cell adhesion, the cell monolayer was washed with phosphate-buffered saline (PBS) and incubated with fresh medium containing various concentrations of test compounds $(10 ; 20 ; 40 ; 60$; and $100 \mu \mathrm{g} / \mathrm{ml})$ for $24 \mathrm{~h}$. Subsequently, $10 \mu \mathrm{L}$ of MTT (Sigma) stock solution $(5 \mathrm{mg} / \mathrm{ml}$ ) was added to each well, and the microplate was incubated for $4 \mathrm{~h}$. After that $100 \mu \mathrm{L}$ of SDS-0.01 M HCl was added to each well followed by incubation for $18 \mathrm{~h}$. Absorbance of converted dye formazan, was measured using a Multiskan FC microplate photometer (Thermo Scientific) at $570 \mathrm{~nm}$ with background subtraction at $630-690 \mathrm{~nm}$.

\subsection{ROS Formation in Macrophage RAW 264.7 Cells}

The cells Raw 264.7 macrophages were plated into 96-well microplates (Costar ${ }^{\circledR}$, Corning, NY) and incubated at $37^{\circ} \mathrm{C}$ with $5 \% \mathrm{CO}_{2}$ for $24 \mathrm{~h}$. After adhesion, cells were incubated with tested compounds at concentrations 10 $\mu \mathrm{g} / \mathrm{ml}$ and LPS $(1.0 \mu \mathrm{g} / \mathrm{ml})$ for another $24 \mathrm{~h}$. To study ROS formation, $20 \mu \mathrm{l}$ of 2,7-dichlorodihydrorofluorescein diacetate $\left(\mathrm{H}_{2} \mathrm{DCF}-\mathrm{DA}\right)$ solution (Molecular Probes, final concentration $10 \mu \mathrm{M}$ ) was added to each well and the microplate was incubated for an additional $10 \mathrm{~min}$ at $37^{\circ} \mathrm{C}$. Prior to fluorescence registration, the cells were washed three times with PBS and then bathed in $200 \mu \mathrm{l} /$ well of PBS. The intensity of dichlorofluorescein fluorescence was measured at $\lambda \mathrm{ex}=485 \mathrm{~nm}$, and $\lambda \mathrm{em}=518 \mathrm{~nm}$ [48]. In each experiment, LPS from $E$. coli serotype 055:B5 (Sigma) were used as a positive control. Fluorescent intensity was measured using plate reader PHERAstar FS (BMG Labtech, Germany).

\subsection{Statistical Analysis}

All assays were performed at least in triplicate. The results are expressed as the mean values (MV) \pm standard deviation (SD). A Student's t-test was used to evaluate the data with the significance level of $\mathrm{p}<0.05$. Figures were built using Microsoft Office Excel.

\section{Results and Discussion}

\subsection{Composition of Extracts of Algae}

The extracts from eight brown algae were prepared with using EtOH/ $\mathrm{CHCl}_{3}$ mixture. These extracts have demonstrated anti-inflammatory activity, which vary considerably in different species of brown algae. Such differences could be explained by the composition of the extracts and by the ratio of the components therein. All extracts have included lipids and PSP (Table 1). Their total content was $0.27 \%-1.30 \%$ of wet weight algae. Lipid moiety was represented neutral lipids (NL), primarily triacylglycerol (TAG), GLs, phospholipids (PL). GLs were the main polar lipids, the contents of which vary over a wide range (Table 1). In PSP were dominated of chlorophylls, but carotenoids were much in some algae also (Table 1). The content of MGDG, DGDG, SQDG, 
Table 1. Composition of brown algae extracts.

\begin{tabular}{|c|c|c|c|c|c|c|c|c|c|c|c|}
\hline \multirow{4}{*}{ Substances } & \multicolumn{11}{|c|}{ Brown algae/month collecting } \\
\hline & \multicolumn{6}{|c|}{$\begin{array}{c}\text { order } \\
\text { Laminariales }\end{array}$} & \multicolumn{2}{|c|}{$\begin{array}{c}\text { order } \\
\text { Dictyotales }\end{array}$} & \multirow{2}{*}{$\begin{array}{c}\begin{array}{c}\text { order } \\
\text { Ectocarpales }\end{array} \\
\begin{array}{c}\text { D. } \\
\text { chordaria }\end{array}\end{array}$} & \multicolumn{2}{|c|}{$\begin{array}{l}\text { order } \\
\text { Fucales }\end{array}$} \\
\hline & \multicolumn{3}{|c|}{$\begin{array}{c}\text { S. } \\
\text { cichorioides }\end{array}$} & \multirow{2}{*}{$\begin{array}{c}\begin{array}{c}C . \\
\text { costata }\end{array} \\
\text { Jul }\end{array}$} & \multirow{2}{*}{$\begin{array}{l}\begin{array}{l}C . \\
\text { filum }\end{array} \\
\text { Sept }\end{array}$} & \multirow{2}{*}{$\begin{array}{c}\begin{array}{c}E . \\
\text { fistulosa }\end{array} \\
\text { Aug }\end{array}$} & \multicolumn{2}{|c|}{$\begin{array}{c}D . \\
\text { divaricata }\end{array}$} & & \multirow{2}{*}{$\begin{array}{c}\text { S. } \\
\text { babingtonii } \\
\text { Nov }\end{array}$} & \multirow{2}{*}{$\begin{array}{c}F . \\
\text { evanescens } \\
\text { Nov }\end{array}$} \\
\hline & Jul & Aug & Nov & & & & Jul & Sept & Sept & & \\
\hline $\begin{array}{c}\text { Sum } \\
\text { substances } \\
\text { in extracts* }\end{array}$ & 0.46 & 0.27 & 0.32 & 0.58 & 0.48 & 0.40 & 0.46 & 1.08 & 0.57 & 0.31 & 1.30 \\
\hline Sum GLs ${ }^{* *}$ & $37.7 \pm 0.9$ & $27.2 \pm 1.0$ & $25.8 \pm 0.9$ & $25.4 \pm 0.72$ & $26.0 \pm 0.8$ & $15.6 \pm 0.5$ & $20.1 \pm 0.7$ & $28.3 \pm 1.2$ & $17.3 \pm 0.4$ & $32.7 \pm 1.0$ & $32.2 \pm 1.6$ \\
\hline MGDG & $18.5 \pm 0.4$ & $8.9 \pm 0.2$ & $8.7 \pm 0.3$ & $11.7 \pm 0.4$ & $7.1 \pm 0.1$ & $5.2 \pm 0.2$ & $7.8 \pm 0.3$ & $13.5 \pm 0.5$ & $8.2 \pm 0.1$ & $8.2 \pm 0.3$ & $10.0 \pm 0.6$ \\
\hline DGDG & $9.0 \pm 0.3$ & $10.3 \pm 0.5$ & $8.0 \pm 0.1$ & $7.5 \pm 0.1$ & $8.0 \pm 0.3$ & $5.0 \pm 0.1$ & $5.4 \pm 0.1$ & $6.2 \pm 0.3$ & $3.8 \pm 0.2$ & $10.7 \pm 0.4$ & $11.4 \pm 0.5$ \\
\hline SQDG & $10.2 \pm 0.2$ & $8.0 \pm 0.3$ & $9.1 \pm 0.5$ & $6.2 \pm 0.21$ & $10.9 \pm 0.4$ & $5.4 \pm 0.2$ & $6.9 \pm 0.3$ & $8.6 \pm 0.4$ & $5.3 \pm 0.1$ & $13.8 \pm 0.3$ & $10.8 \pm 0.5$ \\
\hline Sum $\mathrm{PL}^{* *}$ & $9.2 \pm 0.1$ & $9.2 \pm 0.3$ & $7.2 \pm 0.4$ & $10.3 \pm 0.41$ & $12.5 \pm 0.5$ & $9.1 \pm 0.1$ & $11.2 \pm 0.2$ & $3.1 \pm 0.1$ & $15.2 \pm 0.7$ & $4.5 \pm 0.1$ & $9.6 \pm 0.6$ \\
\hline Sum $\mathrm{NL}^{* *}$ & 15.3 & 17.9 & 22.7 & 38.5 & 34.3 & 11.9 & 22.5 & 34.9 & 29.4 & 28.7 & 36.5 \\
\hline $\mathrm{TAG}^{* * * *}$ & $10.6 \pm 0.4$ & $12.5 \pm 0.3$ & $18.4 \pm 0.7$ & $30.2 \pm 0.92$ & $28.6 \pm 0.8$ & $8.4 \pm 0.3$ & $13.7 \pm 0.7$ & $26.4 \pm 0.9$ & $17.6 \pm 0.4$ & $17.5 \pm 0.4$ & $22.9 \pm 0.7$ \\
\hline Sum PSP $^{* *}$ & $34.8 \pm 0.9$ & $43.0 \pm 1.0$ & $34.1 \pm 1.1$ & $25.7 \pm 0.82$ & $25.0 \pm 0.9$ & $63.4 \pm 1.5$ & $44.8 \pm 1.3$ & $32.5 \pm 0.7$ & $38.1 \pm 1.4$ & $16.7 \pm 0.4$ & $21.7 \pm 0.7$ \\
\hline Chlorophylls & $20.3 \pm 0.4$ & $26.9 \pm 0.5$ & $22.8 \pm 0.6$ & $14.1 \pm 0.1$ & $7.7 \pm 0.1$ & $47.9 \pm 0.7$ & $23.1 \pm 0.4$ & $16.0 \pm 0.2$ & $21.7 \pm 0.4$ & $10.0 \pm 0.2$ & $14.5 \pm 0.3$ \\
\hline Carotenoids & $14.5 \pm 0.5$ & $16.1 \pm 0.5$ & $11.3 \pm 0.5$ & $11.6 \pm 0.71$ & $17.3 \pm 0.8$ & $15.5 \pm 0.8$ & $21.7 \pm 0.9$ & $16.5 \pm 0.5$ & $16.4 \pm 1.0$ & $6.7 \pm 0.2$ & $7.2 \pm 0.4$ \\
\hline Fucoxanthin $^{* * *}$ & $7.9 \pm 0.2$ & $8.3 \pm 0.2$ & $7.1 \pm 0.4$ & $6.5 \pm 0.3$ & $8.9 \pm 0.6$ & $8.3 \pm 0.4$ & $9.9 \pm 0.7$ & $9.0 \pm 0.2$ & $12.9 \pm 0.8$ & $4.6 \pm 0.1$ & $4.3 \pm 0.2$ \\
\hline
\end{tabular}

Data presented ${ }^{*}$ as $\%$ of wet weight alga $(\mathrm{SD}<0.04),{ }^{* *}$ as $\%$ of total content substances in extracts. ${ }^{* * *}$ shown only TAG content and only fucoxanthin. The content of substances are presented as MV \pm SD of three replicate assays.

and carotenoids showed species-specific differences and has depended on the month of collecting the algae (Table 1).

\subsection{Anti-Inflammatory Activity of Extracts and Some Their Components}

The anti-inflammatory activity of the algal extracts and substances was tested in RAW 264.7 macrophage cells. Preliminarily cell viability was measured using MTT assay [47]. The RAW 264.7 murine macrophage cells were treated with varying concentrations $(10.0,20.0,40.0,60$ and $100 \mu \mathrm{g} / \mathrm{ml})$ extracts. The results showed that algal extracts did not affect cell viability within this a concentrations range (Figure not shown) and $10 \mu \mathrm{g} / \mathrm{ml}$ as minimal concentration of extracts was chosen as for investigations.

Algal extracts, for exception of C. costata and E. fistulosa extracts, showed barely noticeable increase in ROS formation in RAW 264.7 macrophage cells compared with pro-inflammatory endotoxin lipopolysaccharide from E. coli, which generated a large amount of ROS in macrophages (Figure 1).

Further RAW 264.7 macrophage cells were stimulating with LPS from E. coli, which generated a large amount of ROS in them. These LPS-stimulated macrophage cells were treated by algal extracts. Extracts showed different abilities to suppress of ROS in LPS-stimulated cells (Figure 2). Among of tested extracts, extracts of $D$. divaricata, D. chordaria, C. filum and S. cichorioides, S. babingtonii and F. evanescens showed strongest inhibitory effect. They reduced the level of ROS at the 30\% - 55\% relatively positive control of LPS (Figure 2). Extracts S. cichorioides (collected in August), C. costata and E. fistulosa were weaker. They lowered the ROS level only by $12 \%$ - 27\% (Figure 2). Algae S. cichorioides and D. divaricata were collected in different months and this affected the degree of suppression of the ROS. Extracts of S. cichorioides, which were collected in July and November decreased ROS level by 30\% - 31\% and the samples collected in August reduced him on 27\%. Extract of $D$. divaricata collected in July reduced the level of ROS by $55 \%$, while the extract of this alga that was collected in September lowered him on 33\%. Obviously, the species of algae and month of collection have an impact on the degree of suppression of ROS.

As shown earlier, algae produce many glyceroglycolipids [49] [50] and fucoxanthin among carotenoids of brown algae is the main component [51]-[54]. As indicated above, some species of brown algae of the Sea of 


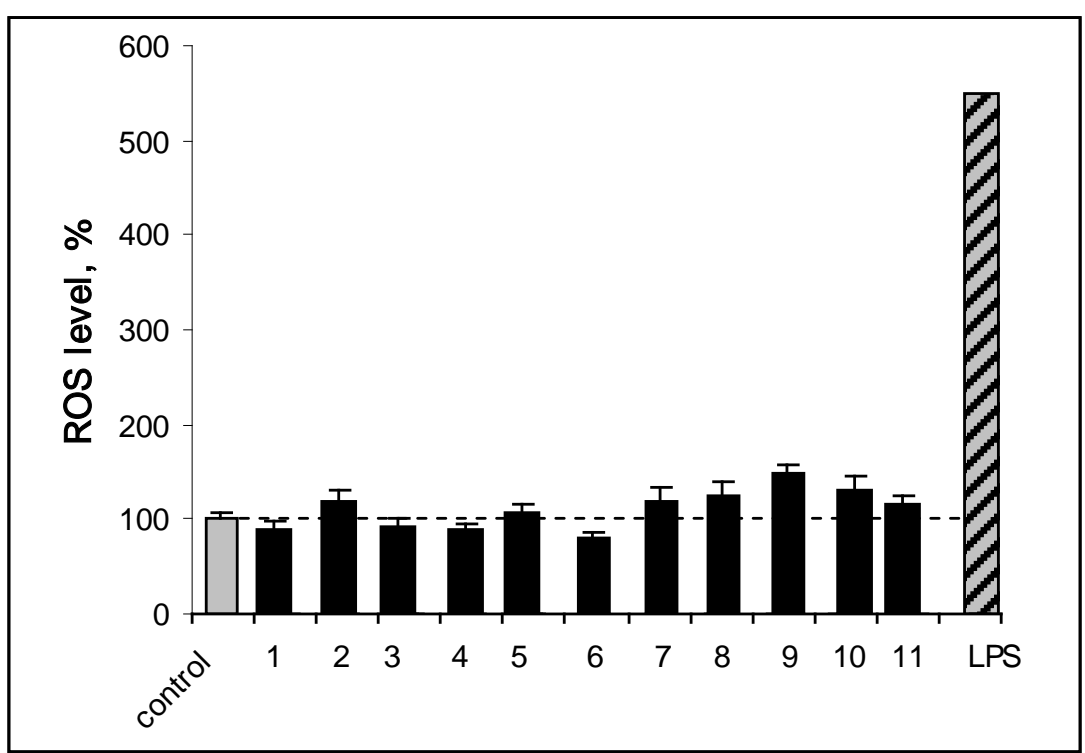

Figure 1. Effect of algal extracts on ROS formation in RAW 264.7 murine macrophages. Extracts were obtained from algae S. cichorioides (collected in 1-July, 2-August, 3-November), C. costata (4), C. filum (5), E. fistulosa (6), D. divaricata (collected in 7-July, 8-September), D. chordaria (9), S. babingtonii (10), F. evanescens (11), LPS-positive control. Time of cell incubation with extracts is $24 \mathrm{~h}$ at $37^{\circ} \mathrm{C}$.

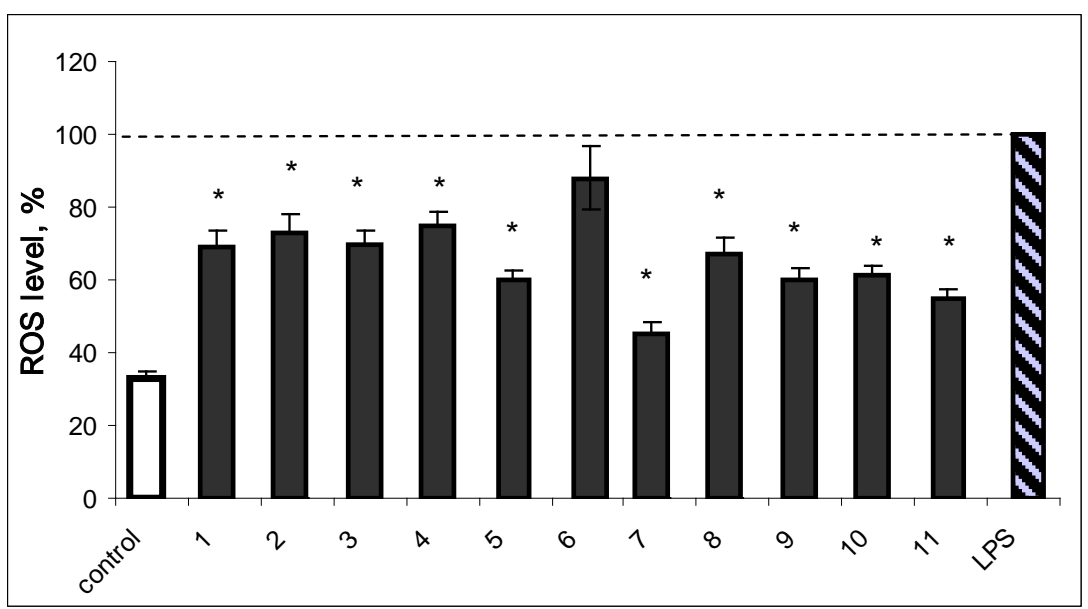

Figure 2. Effect of algal extracts on ROS in LPS-stimulated RAW 264.7 murine macrophages. Extracts obtained from algae S. cichorioides (collected in 1-July, 2-August, 3-November), C. costata (4), C. filum (5), E. fistulosa (6), D. divaricata (collected in 7-July, 8-September), D. chordaria (9), S. babingtonii (10), F. evanescens (11). Time of cell incubation with extracts is $24 \mathrm{~h}$ at $37^{\circ} \mathrm{C}$. ${ }^{*} \mathrm{p}<0.05$.

Japan contain large quantities of GLs and fucoxanthin (Table 1). Polar lipids [31] [32] [55] and fucoxanthin [28] [29] are of interest as anti-inflammatory agents. Therefore GLs and fucoxanthin were isolated by column chromatography for investigation their ability to suppress of ROS. All GLs showed no cytotoxic effect and not stimulated ROS formation in RAW 264.7 cells. On the contrary, they are suppressed ROS in LPS-stimulated RAW 264.7 macrophages.

MGDG from three species algae: E. fistulosa, D. divaricata, and C. filum (first group) have high activity, decreasing ROS level in LPS-stimulated RAW 264.7 macrophages at 52\% - 58\% (Figure 3) relatively of LPS. MGDG of $D$. chordaria, F. evanescens and S. babingtonii have middle activity (second group) and they lowered the ROS level by 33\% - 35\%, but MGDG S. cichorioides and C. costata (third group) reduce ROS level by 17\% - 


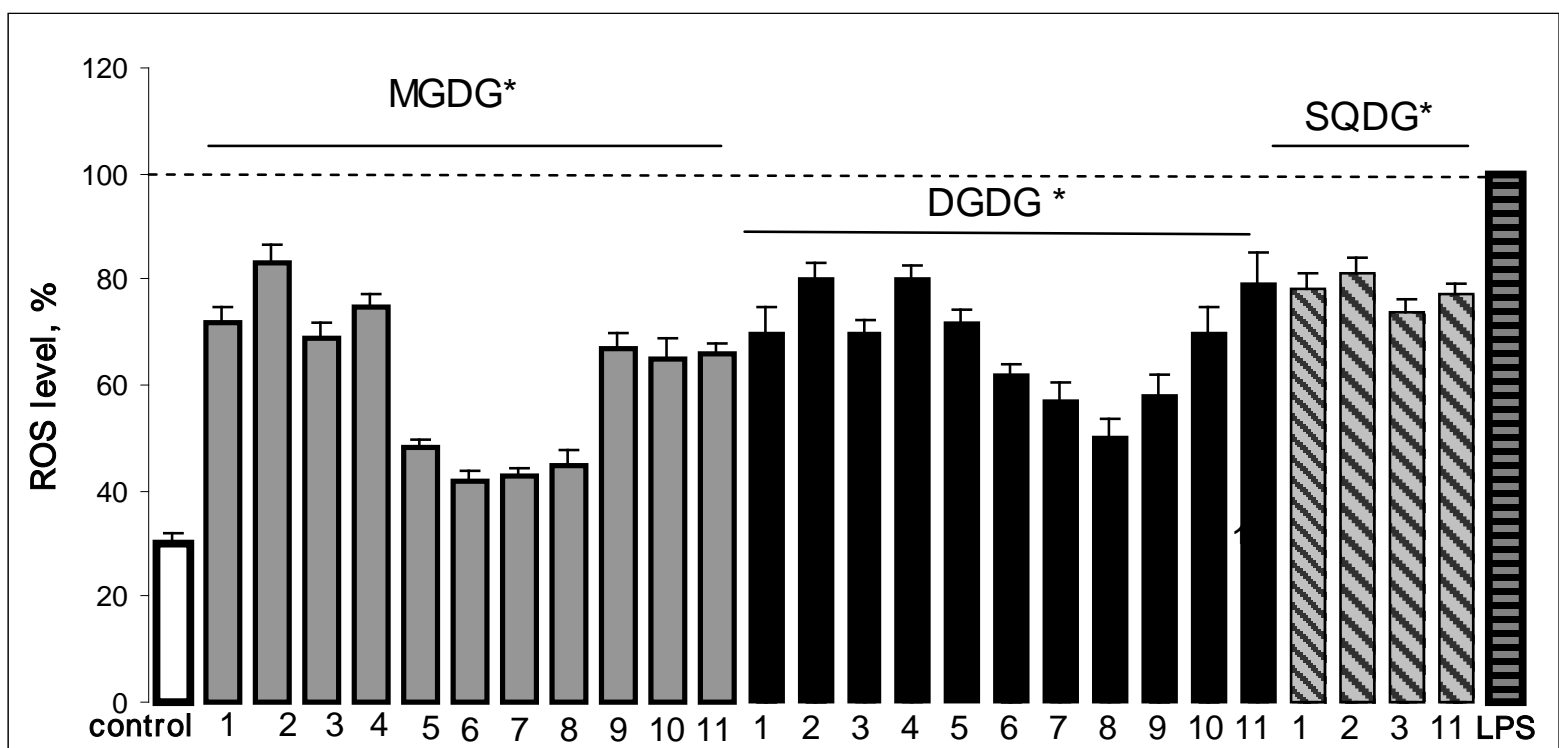

Figure 3. Effect of MGDG, DGDG, and SQDG on ROS in LPS-stimulated RAW 264.7 murine macrophages. MGDG and DGDG were obtained from S. cichorioides (1-July, 2-August, 3-November), C. costata (4), C. filum (5), E. fistulosa (6), D. divaricata (7-July, 8-September), D. chordaria (9), S. babingtonii (10), F. evanescens (11) and SQDG-from S. cichorioides (1-July, 2-August, 3-November), and F. evanescens (11). Time of cell incubation with GLs is $24 \mathrm{~h}$ at $37^{\circ} \mathrm{C} .{ }^{*} \mathrm{p}<0.05$.

31\% (Figure 3). Month of collecting the algae has influenced on suppression of ROS. So, MGDG from seaweed S. cichorioides, which were collected in August, weaker inhibited ROS than MGDG algae collected in July and November. MGDG D. divaricata that were collected in July and September decreased ROS levels in equal measure (Figure 3).

DGDG can be divided into two groups according to the degree of inhibition. The first group consists of the DGDG with a low degree of inhibition, which were isolated from S. cichorioides, C. costata, C. filum, F. evanescens and S. babingtonii. They suppressed of ROS by $20 \%-30 \%$ (Figure 3). The second group were of DGDG of E. fistulosa, D. divaricata, and D. chordaria that had high activity. They lowered the level ROS by $38 \%$ - 50\% relatively of LPS (Figure 3). Among these brown algae, DGDG of D. divaricata was the strongest a suppressor (Figure 3).

SQDG were isolated from extracts of $S$. cichorioides that were collected in July, August, and November, and also F. evanescens. All SQDG had weaker activity than galactolipids MGDG and DGDG (Figure 3).

As shown, fucoxanthin well suppresses the production of inflammatory mediators [28] [29]. He was isolated by column chromatography from extracts several algae as C. filum, D. chordaria and D. divaricata for comparison his activity. Purity of carotenoids was examinated by TLC. Fucoxanthin from C. filum contained small amount chlorophyll $a$ and fucoxanthinol and from $D$. chordaria he was pure. Fucoxanthin of D. divaricata, which was collected in July and in September, was separate on two fractions: pure of fucoxanthin and fucoxanthin together with its metaboliteas fucoxanthinol. Pure fucoxanthin from different algae suppressed the ROS a greater degree, by 55\% - 60\%, whereas fucoxanthin with impurity other pigments showed low level of suppression of ROS that was in range by $20 \%-50 \%$ (Figure 4). Chlorophyll $c$ not was active, but chlorophyll $c_{1}$ lowered level of ROS by 23\% (Figure 4). These pigments did not affected cell viability and they not stimulated ROS formation in RAW 264.7 cells.

Thus, GLs and pigments demonstrated ROS-inhibitory activity. Extracts of algae are complex mixtures of lipids and PSP and synergistic effect manifested as collective influence of their on the activity. In addition, quantitative content of components in the extracts could influence the level of their activity. This is especially noticeable for algae E. fistulosa, which included very few polar lipids and many pigments (Table 1) and C. costata with high content pro-inflammatory fatty acids (Table 2).

\subsection{Influence of Fatty Acids on Anti-Inflammatory Properties of Extracts and GLs}

As shown in several studies, the activity of the lipid extracts depends on the composition and ratio of fatty acids 


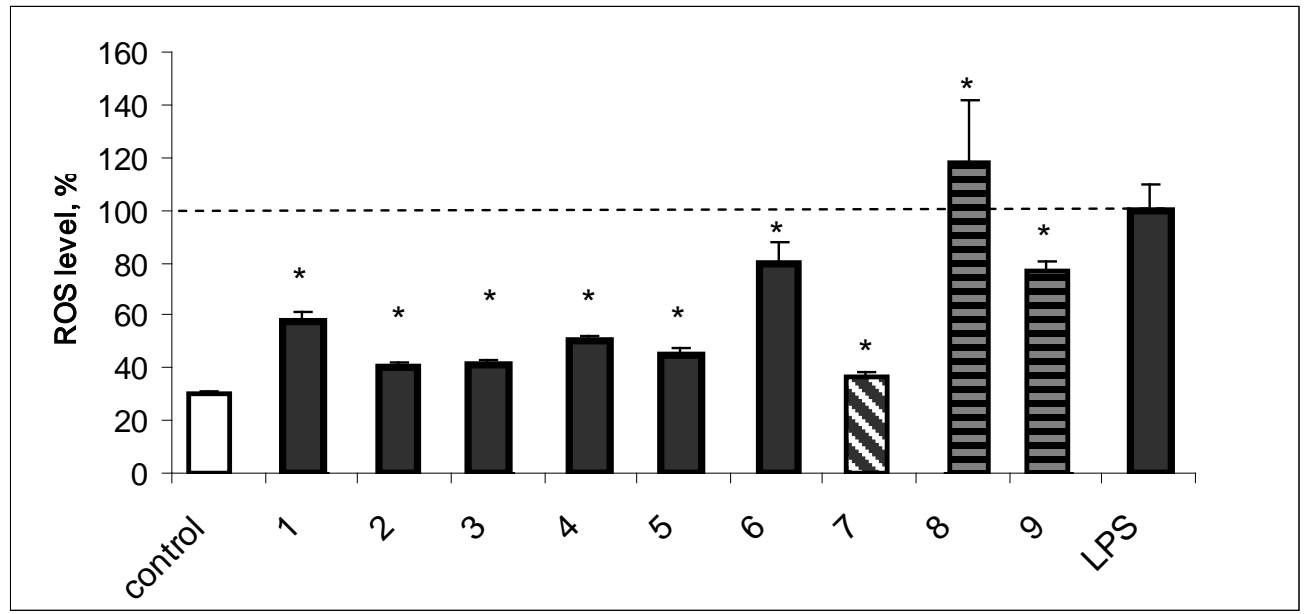

Figure 4. Effect PSP on ROS in LPS-stimulated RAW 264.7 murine macrophages. 1-fucoxanthin of $C$. filum with traces chlorophyll $a$ and fucoxanthinol; 2-pure fucoxanthin of $D$. chordaria; 3 and 5-pure fucoxanthin, 4 and 6-fucoxanthin with fucoxanthinol from $D$. divaricata collected in July and September respectively; 7-fucoxanthin Sigma-Aldrich; 8-chlorophyll $c$; 9-chlorophyll $c_{1}$. Time of cell incubation with PSP is $24 \mathrm{~h}$ at $37^{\circ} \mathrm{C} .{ }^{*} \mathrm{p}<0.05$.

in them [23] [34]. It is believe, that a low $n-6 / n-3$ ratio may be one of the factors influencing their anti-inflammatory properties [23]. These assumptions were based on experimental studies, which showed that incorporation of $n-3$ PUFA modifies inflammatory and immune reactions, making $n-3$ PUFA potential therapeutic agents for inflammatory and autoimmune diseases. The ratio $n-6 / n-3$ as $1-4 / 1$ rather than the ratio of $20-16 / 1$ from diets is more physiologic [56] [57].

Research FAs of EtOH/ $\mathrm{CHCl}_{3}$ extracts showed that they had a high proportion of polyunsaturated fatty acids (PUFA), which was of the order of $36.6 \%-59.0 \%$, but the level saturated FAs (SFA) and monounsaturated (MUFA) FAs was also relatively high (Table 2). In extracts with high levels of suppression of ROS had greater of PUFA. As considered, fatty acids 18:3n - 3 (ALA), 18:4n- 3 and 20:5n - 3 (EPA) has anti-inflammatory function [58]-[60], while 18:2n-6 (LA) and 20:4n - 6 (AA) showed of pro-inflammatory properties [59] [60]. The content 18:3n-3,18:4n-3 and 20:5n-3 varied in broad range in extracts of different algae. However, $n-3$ PUFA were dominant PUFA in extracts with high activity. The exception was an extract of $D$. divaricata (September), which had an equal ratio $n-3$ and $n-6$ PUFA (Table 2). As a rule, all extracts, for exception extract of $D$. divaricata, have a low ratios $n-6 / n-3$ PUFA and LA + AA/ALA + EPA. Ratio $n-6 / n-3$ was in range 0.38 - 0.99 and ratio LA + AA/ALA + EPA was 0.51 - 0.98. In less active extracts S. cichorioides (collected in August) and C. costata there were many of PUFA. However, PUFA content in this extract of $S$. cichorioides was lowest, but the proportions of $n-6$ and $n-3$ PUFA were close, and in the extract $C$. costata, which had a high amount of PUFA dominated of $n-6$ PUFA. Ratio $n-6 / n-3$ was in range $0.98-1.11$ and ratio LA + AA/ALA + EPA was 1.39 - 1.42. Extracts of S. cichorioides and D. divaricata that showed changes in activity depending on the month of collecting the algae had appreciable differences in the amount of SFA, MUFA and PUFA and in the ratios of $n-6 / n-3$ and LA + AA/ALA + EPA (Table 2). It should be noted that in the extract of $E$. fistulosa PUFA was greater than 54\%, and in them dominated of $n-3$ PUFA, but the activity of this extract was the lowest. As can be seen, algae extracts are complex mixtures (Table 1). In extract of E. fistulosa was dominated by the pigments (above 63\%), mainly chlorophylls, and there were not much of polar lipids (24.7\%), and TAG (8.4\%). Inhibition of ROS is likely, occurred due to the synergistic action of the various components including FAs of lipids. Probably that low suppression of the ROS was due to high content of PSP and the lower percentage of lipids in extract of E. fistulosa.

Natural GLs always exist as mixtures molecular species because of the diversity composition of FAs. We studied influence of FAs natural GLs on suppression ROS, although recent works have investigated anti-inflammatory properties only their molecular species [31] [32] [61] [62]. Variations of FAs content of GLs brown algae shown in Table 3.

In MGDG of the first group, which included C. filum, E. fistulosa, and D. divaricata, the amount of SFA, 
Table 2. Fatty acids composition (\% of the total FAs) of the extracts of brown algae.

\begin{tabular}{|c|c|c|c|c|c|c|c|c|c|c|c|}
\hline \multirow[t]{2}{*}{ FAs } & \multicolumn{3}{|c|}{$\begin{array}{c}\text { S. } \\
\text { cichorioides }\end{array}$} & \multirow{2}{*}{$\begin{array}{c}\text { C. } \\
\text { costata }\end{array}$} & \multirow{2}{*}{$\begin{array}{c}\begin{array}{l}C . \\
\text { filum }\end{array} \\
\text { Sept }\end{array}$} & \multirow{2}{*}{$\begin{array}{c}\begin{array}{c}E . \\
\text { fistulosa }\end{array} \\
\text { Aug }\end{array}$} & \multicolumn{2}{|c|}{$\begin{array}{c}D . \\
\text { divaricata }\end{array}$} & \multirow{2}{*}{$\begin{array}{c}\text { D. } \\
\text { chordaria }\end{array}$} & \multirow{2}{*}{$\begin{array}{c}\text { S. } \\
\text { babingtoni } \\
\text { Nov }\end{array}$} & \multirow{2}{*}{$\begin{array}{c}F . \\
\text { evanescens } \\
\text { Nov }\end{array}$} \\
\hline & Jul & Aug & Nov & & & & Jul & Sept & & & \\
\hline $14: 0$ & $6.7 \pm 0.5$ & $8.5 \pm 0.2$ & $6.4 \pm 0.3$ & $6.7 \pm 0.4$ & $5.1 \pm 0.2$ & $3.5 \pm 0.3$ & $8.8 \pm 0.4$ & $9.2 \pm 0.3$ & $4.3 \pm 0.2$ & $3.1 \pm 0.3$ & $2.1 \pm 0.0$ \\
\hline $15: 0$ & $1.4 \pm 0.2$ & & & & $0.3 \pm 0.0$ & $0.4 \pm 0.0$ & $0.1 \pm 0.0$ & $0.9 \pm 0.0$ & $0.2 \pm 0.0$ & $0.4 \pm 0.0$ & $0.1 \pm 0.0$ \\
\hline $16: 0$ & $19.2 \pm 1$. & $23.1 \pm 0.8$ & $15.8 \pm 0.6$ & $19.4 \pm 0.5$ & $23.6 \pm 0.9$ & $28.2 \pm 0.7$ & $20.4 \pm 0.6$ & $22.6 \pm 0.8$ & $27.0 \pm 1.0$ & $17.0 \pm 0.5$ & $15.8 \pm 0.7$ \\
\hline $16: 1 n-5$ & & $0.2 \pm 0.0$ & & & $0.1 \pm 0.0$ & & $2.0 \pm 0.0$ & $1.4 \pm 0.0$ & $0.7 \pm 0.0$ & $0.3 \pm 0.0$ & $1.0 \pm 0.0$ \\
\hline $16: \ln -7$ & $9.4 \pm 0.8$ & $6.6 \pm 0.3$ & $4.0 \pm 0.2$ & $2.6 \pm 0.1$ & $0.4 \pm 0.0$ & $0.7 \pm 0.0$ & $2.3 \pm 0.1$ & $1.8 \pm 0.1$ & $0.4 \pm 0.0$ & $2.6 \pm 0.1$ & $0.4 \pm 0.0$ \\
\hline $16: 1 n-9$ & & & & $0.1 \pm 0.0$ & $0.2 \pm 0.0$ & & $0.8 \pm 0.0$ & $0.5 \pm 0.0$ & $0.4 \pm 0.0$ & $0.4 \pm 0.0$ & $1.0 \pm 0.0$ \\
\hline $16: 2 n-4$ & & & & $0.9 \pm 0.0$ & & & $0.3 \pm 0.0$ & & & & \\
\hline $16: 2 n-6$ & $0.8 \pm 0.0$ & $0.2 \pm 0.0$ & $0.5 \pm 0.0$ & $0.1 \pm 0.0$ & & $0.7 \pm 0.0$ & $0.2 \pm 0.0$ & & & & \\
\hline $16: 4 n-1$ & & & & $0.1 \pm 0.0$ & & & & & & & \\
\hline 18:0 & $0.9 \pm 0.0$ & $0.8 \pm 0.0$ & $2.0 \pm 0.0$ & $1.7 \pm 0.1$ & $0.3 \pm 0.0$ & $1.2 \pm 0.0$ & $0.3 \pm 0.0$ & $0.5 \pm 0.0$ & $0.9 \pm 0.0$ & $0.6 \pm 0.0$ & $0.2 \pm 0.0$ \\
\hline $18: \ln -7$ & $1.1 \pm 0.0$ & & $1.3 \pm 0.0$ & $0.3 \pm 0.0$ & $0.5 \pm 0.0$ & $0.1 \pm 0.0$ & $0.7 \pm 0.1$ & $0.8 \pm 0.0$ & $1.1 \pm 0.0$ & $0.2 \pm 0.0$ & $1.2 \pm 0.0$ \\
\hline $18: 1 n-9$ & $15.3 \pm 0.5$ & $24.0 \pm 0.7$ & $15.9 \pm 0.7$ & $18.4 \pm 0.8$ & $16.6 \pm 0.7$ & $11.1 \pm 0.4$ & $12.0 \pm 0.8$ & $13.8 \pm 0.3$ & $9.6 \pm 0.5$ & $20.1 \pm 0.7$ & $18.9 \pm 0.6$ \\
\hline $18: 2 n-6(L A)$ & $8.5 \pm 0.6$ & $6.7 \pm 0.4$ & $8.6 \pm 0.5$ & $7.9 \pm 0.3$ & $10.6 \pm 0.4$ & $3.7 \pm 0.2$ & $8.4 \pm 0.5$ & $10.3 \pm 0.6$ & $6.9 \pm 0.3$ & $12.3 \pm 0.6$ & $10.2 \pm 0.3$ \\
\hline $18: 3 n-3(A L A)$ & $8.3 \pm 0.4$ & $0.4 \pm 0.0$ & $5.3 \pm 0.2$ & $6.6 \pm 0.2$ & $8.0 \pm 0.2$ & $8.7 \pm 0.5$ & $16.1 \pm 0.4$ & $11.0 \pm 0.8$ & $8.8 \pm 0.6$ & $13.6 \pm 0.5$ & $14.2 \pm 0.7$ \\
\hline $18: 3 n-6$ & $1.2 \pm 0.0$ & & $0.6 \pm 0.0$ & $1.5 \pm 0.1$ & & $0.2 \pm 0.0$ & $2.1 \pm 0.1$ & $3.2 \pm 0.0$ & $2.0 \pm 0.0$ & $1.0 \pm 0.0$ & $2.3 \pm 0.1$ \\
\hline $18: 4 n-3$ & $5.5 \pm 0.2$ & $5.7 \pm 0.2$ & $5.5 \pm 0.3$ & $7.0 \pm 0.6$ & $11.4 \pm 0.7$ & $13.0 \pm 0.6$ & $9.8 \pm 0.4$ & $7.1 \pm 0.6$ & $15.1 \pm 0.4$ & $6.4 \pm 0.2$ & $10.3 \pm 0.5$ \\
\hline $20: 0$ & $0.3 \pm 0.0$ & $0.2 \pm 0.0$ & $1.3 \pm 0.1$ & $0.2 \pm 0.0$ & $0.3 \pm 0.0$ & $0.3 \pm 0.0$ & $0.5 \pm 0.0$ & $0.2 \pm 0.0$ & $0.2 \pm 0.0$ & $0.5 \pm 0.0$ & $0.3 \pm 0.0$ \\
\hline $20: 1 n-9$ & $0.2 \pm 0.0$ & & & $0.1 \pm 0.0$ & & & & & & & \\
\hline $20: 2 n-6$ & $0.1 \pm 0.0$ & $0.1 \pm 0.0$ & $1.5 \pm 0.0$ & $0.9 \pm 0.0$ & & & & & $0.3 \pm 0.0$ & & \\
\hline $20: 4 n-6(A A)$ & $9.4 \pm 0.7$ & $11.1 \pm 0.5$ & $15.5 \pm 0.4$ & $15.6 \pm 0.5$ & $9.4 \pm 0.6$ & $14.2 \pm 0.5$ & $9.0 \pm 0.3$ & $10.6 \pm 0.4$ & $5.9 \pm 0.2$ & $10.6 \pm 0.5$ & $9.9 \pm 0.4$ \\
\hline $20: 5 n-3(E P A)$ & $11.7 \pm 1.0$ & $12.4 \pm 0.4$ & $15.8 \pm 0.6$ & $9.9 \pm 0.5$ & $13.2 \pm 0.8$ & $14.0 \pm 0.5$ & $6.2 \pm 0.3$ & $6.0 \pm 0.2$ & $16.2 \pm 0.5$ & $10.9 \pm 0.7$ & $12.1 \pm 0.4$ \\
\hline$\sum \mathrm{SFA}$ & $28.5 \pm 1.9$ & $32.6 \pm 1.0$ & $25.5 \pm 1.0$ & $28.0 \pm 1.0$ & $29.6 \pm 1.1$ & $33.6 \pm 1.0$ & $30.1 \pm 1.0$ & $33.4 \pm 1.1$ & $32.6 \pm 1.2$ & $21.6 \pm 0.8$ & $18.5 \pm 0.7$ \\
\hline$\sum$ MUFA & $26.0 \pm 1.3$ & $30.8 \pm 1.0$ & $21.2 \pm 0.9$ & $21.5 \pm 0.9$ & $17.8 \pm 0.7$ & $11.9 \pm 0.4$ & $17.8 \pm 1.0$ & $18.3 \pm 0.4$ & $12.2 \pm 0.5$ & $23.6 \pm 0.7$ & $22.5 \pm 0.6$ \\
\hline$\sum$ PUFA & $45.5 \pm 2.9$ & $36.6 \pm 1.5$ & $53.3 \pm 2.0$ & $50.5 \pm 2.2$ & $52.6 \pm 2.7$ & $54.5 \pm 2.3$ & $52.1 \pm 2.0$ & $48.3 \pm 2.6$ & $55.2 \pm 2.0$ & $54.8 \pm 2.5$ & $59.0 \pm 2.4$ \\
\hline$\sum n-6$ PUFA & $20.0 \pm 1.3$ & $18.1 \pm 0.9$ & $26.7 \pm 0.9$ & $26.0 \pm 0.9$ & $20.0 \pm 1.0$ & $18.8 \pm 0.7$ & $19.7 \pm 0.9$ & $24.1 \pm 1.0$ & $15.1 \pm 0.5$ & $23.9 \pm 1.1$ & $22.4 \pm 0.8$ \\
\hline$\sum \mathrm{n}-3$ PUFA & $25.5 \pm 1.6$ & $18.5 \pm 0.6$ & $26.6 \pm 1.1$ & $23.5 \pm 1.3$ & $32.6 \pm 1.7$ & $35.7 \pm 1.6$ & $32.1 \pm 1.1$ & $24.2 \pm 1.6$ & $40.1 \pm 1.5$ & $30.9 \pm 1.4$ & $36.6 \pm 1.6$ \\
\hline$n-6 / n-3$ & 0.78 & 0.98 & 1.0 & 1.11 & 0.61 & 0.52 & 0.61 & 0.99 & 0.38 & 0.77 & 0.61 \\
\hline $\mathrm{LA}+\mathrm{AA} / \mathrm{ALA}+\mathrm{EPA}$ & 0.90 & 1.39 & 1.14 & 1.42 & 0.94 & 0.79 & 0.78 & 1.18 & 0.51 & 0.98 & 0.76 \\
\hline
\end{tabular}

MUFA and PUFA was varied in a wide range but $n-3$ PUFA prevailed among PUFA (Table 3). MGDG E. fistulosa, which had highest activity, was most noticeable in the content of $\mathrm{n}-3$ PUFA, which was about $73 \%$. Less all $n-3$ PUFA was in MGDG C. filum (about 20\%) and there was many SFA and MUFA. In MGDG $D$. divaricata collected in July also had a lot of $n-3$ PUFA (about 42\%), but in MGDG of September algae $n-3$ PUFA was comparatively little (29\%). At the same time, in these MGDG had enough many n - 6 PUFA, regardless of the month of collection. Ratio $n-6 / n-3$ for algae of the first group was in range $0.12-0.59$ and ratios LA + AA/ALA + EPA were $0.28-0.81$. The lowest ratio of $n-6 / n-3$ had MGDG E. fistulosa, which was 0.12. In this alga had also very little of $n-6$ PUFA. MGDG from $D$. chordaria, F. evanescens and $S$. babingtonii, which showed middle activity possessed also pretty low ratio $n-6 / n-3$ that was $0.56-0.82$, but ratio LA + AA/ALA + EPA was $>1$. In MGDG were many PUFA and $n-3$ PUFA there are predominated. MGDG with a 
Table 3. Fatty acids compositions (\% of the total FAs) of the glyceroglycolipids of brown algae.

\begin{tabular}{|c|c|c|c|c|c|c|c|c|c|c|c|}
\hline \multirow{3}{*}{ FAs } & \multicolumn{11}{|c|}{ MGDG } \\
\hline & \multicolumn{3}{|c|}{$\begin{array}{c}\text { S. } \\
\text { cichorioides }\end{array}$} & \multirow{2}{*}{$\begin{array}{c}\text { C. } \\
\text { costata }\end{array}$} & \multirow{2}{*}{$\begin{array}{c}\text { C. } \\
\text { filum } \\
\text { Sept }\end{array}$} & \multirow{2}{*}{$\begin{array}{c}\text { E. } \\
\text { fistulosa } \\
\text { Aug }\end{array}$} & \multicolumn{2}{|c|}{$\begin{array}{c}D . \\
\text { divaricata }\end{array}$} & \multirow{2}{*}{$\begin{array}{c}\begin{array}{c}D . \\
\text { chordaria }\end{array} \\
\text { Sept }\end{array}$} & \multirow{2}{*}{$\begin{array}{c}\text { S. } \\
\text { babingtonii } \\
\text { Nov }\end{array}$} & \multirow{2}{*}{$\begin{array}{c}F . \\
\text { evanescens } \\
\text { Nov }\end{array}$} \\
\hline & Jul & Aug & Nov & & & & Jul & Sept & & & \\
\hline $14: 0$ & 24.5 & 27.4 & 8.8 & 31.6 & 10.4 & 5.4 & 14.6 & 13.2 & 5.7 & 8.7 & 11.0 \\
\hline $15: 0$ & 1.1 & 1.4 & & 0.4 & 1.2 & & 0.3 & & & 0.2 & 0.9 \\
\hline $16: 0$ & 19.9 & 20.6 & 16.0 & 14.7 & 27.4 & 4.9 & 11.2 & 22.5 & 24.6 & 9.6 & 22.3 \\
\hline $16: 1 n-5$ & - & 0.5 & & 0.7 & 0.3 & & 1.7 & 3.1 & 0.7 & 1.4 & 2.0 \\
\hline $16: 1 n-7$ & 18.0 & 16.4 & 7.6 & 12.9 & 5.5 & 1.0 & 1.9 & 0.3 & 0.4 & 0.6 & 0.4 \\
\hline $16: 1 n-9$ & & & & 0.1 & 0.1 & 0.9 & 0.2 & & & 0.4 & \\
\hline $16: 2 n-4$ & & & & 3.2 & & & 0.1 & & & & \\
\hline $16: 2 n-6$ & 1.2 & 0.4 & 2.7 & 0.5 & & 0.8 & 0.3 & & & & \\
\hline $16: 4 n-1$ & & & & 0.5 & & 1.6 & & & & & \\
\hline 18:0 & 1.9 & 3.0 & 4.5 & 0.4 & 1.5 & 0.2 & 0.1 & 0.5 & 3.7 & 0.2 & 0.9 \\
\hline $18: 1 n-7$ & & 1.2 & & 0.7 & 0.5 & 0.1 & 0.1 & 0.5 & 0.3 & 0.1 & 0.1 \\
\hline $18: 1 n-9$ & 21.9 & 27.0 & 8.9 & 13.3 & 26.9 & 4.2 & 9.0 & 13.7 & 16.3 & 9.8 & 12.2 \\
\hline $18: 2 n-6(L A)$ & 4.2 & 1.8 & 8.5 & 9.4 & 4.7 & 3.3 & 11.1 & 13.0 & 10.6 & 16.7 & 14.3 \\
\hline $18: 3 n-3($ ALA $)$ & 0.4 & & 2.0 & 2.6 & 13.8 & 3.2 & 22.7 & 19.5 & 5.7 & 11.3 & 9.4 \\
\hline $18: 3 n-6$ & 3.2 & & 6.1 & 1.3 & & 2.6 & 1.1 & 0.6 & 5.7 & 4.1 & 1.4 \\
\hline $18: 4 n-3$ & 1.2 & & 4.0 & 3.0 & 4.3 & 53.7 & 16.2 & 8.6 & 13.2 & 25.2 & 11.2 \\
\hline $20: 0$ & 0.2 & 0.3 & & 0.1 & 0.6 & 0.1 & 0.3 & & 0.3 & & 0.1 \\
\hline $20: 1 n-9$ & 0.6 & & & 0.2 & & & & & & & \\
\hline $20: 4 n-6(A A)$ & 0.9 & & & 2.0 & 1.2 & 2.0 & 5.4 & 3.6 & 6.4 & 4.1 & 5.8 \\
\hline $20: 5 n-3($ EPA $)$ & 0.8 & & 5.8 & 2.0 & 1.6 & 16.0 & 3.4 & 0.9 & 7.3 & 7.6 & 8.0 \\
\hline$\sum \mathrm{SFA}$ & 47.6 & 52.7 & 43.3 & 47.2 & 41.1 & 10.6 & 26.7 & 34.2 & 34.3 & 18.6 & 35.2 \\
\hline$\sum$ MUFA & 40.5 & 45.1 & 16.5 & 27.9 & 33.3 & 6.2 & 12.9 & 19.6 & 18.0 & 12.0 & 14.7 \\
\hline$\sum$ PUFA & 11.9 & 2.2 & 40.2 & 24.9 & 25.6 & 83.2 & 60.4 & 46.2 & 47.7 & 69.4 & 50.1 \\
\hline$\sum \bar{n}-6$ PUFA & 9.5 & 2.2 & 23.1 & 13.6 & 5.9 & 8.7 & 17.9 & 17.2 & 21.5 & 24.9 & 21.5 \\
\hline$\sum n-3$ PUFA & 2.4 & & 17.1 & 7.6 & 19.7 & 72.9 & 42.3 & 29.0 & 26.2 & 44.1 & 28.6 \\
\hline$n-6 / n-3$ & 3.96 & 0 & 1.35 & 1.79 & 0.30 & 0.12 & 0.42 & 0.59 & 0.82 & 0.56 & 0.75 \\
\hline $\mathrm{LA}+\mathrm{AA} / \mathrm{ALA}+\mathrm{EPA}$ & 4.25 & 0 & 1.09 & 2.48 & 0.38 & 0.28 & 0.63 & 0.81 & 1.31 & 1.10 & 1.16 \\
\hline \multirow{3}{*}{ FAs } & \multicolumn{11}{|c|}{ DGDG } \\
\hline & \multicolumn{3}{|c|}{$\begin{array}{c}\text { S. } \\
\text { cichorioides }\end{array}$} & $\begin{array}{c}\text { C. } \\
\text { costata }\end{array}$ & $\begin{array}{l}\text { C. } \\
\text { filum }\end{array}$ & $\begin{array}{c}\text { E. } \\
\text { fistulosa }\end{array}$ & \multicolumn{2}{|c|}{$\begin{array}{c}D . \\
\text { divaricata }\end{array}$} & $\begin{array}{c}\text { D. } \\
\text { chordaria }\end{array}$ & $\begin{array}{c}\text { S. } \\
\text { babingtonii }\end{array}$ & $\begin{array}{c}F . \\
\text { evanescens }\end{array}$ \\
\hline & Jul & Aug & Nov & Jul & Sept & Aug & Jul & Sept & Sept & Nov & Nov \\
\hline $14: 0$ & 6.3 & 9.9 & 3.1 & 8.4 & 10.9 & 5.4 & 0.9 & 0.1 & 4.9 & 7.5 & 3.3 \\
\hline $15: 0$ & 0.4 & & & & 0.8 & 0.7 & 0.2 & & & 0.4 & \\
\hline $16: 0$ & 11.5 & 30.8 & 26.7 & 26.8 & 30.7 & 31.1 & 43.7 & 35.3 & 22.9 & 26.7 & 39.3 \\
\hline $16: 1 n-5$ & & & & 1.0 & & 0.2 & 0.9 & 3.6 & & 0.1 & \\
\hline $16: 1 n-7$ & 13.2 & 1.9 & 7.5 & 20.6 & 0.7 & 7.7 & 2.1 & 1.0 & 1.3 & 1.9 & 2.2 \\
\hline $16: 1 n-9$ & 0.4 & 0.6 & & 0.3 & & 0.3 & 0.2 & 13.4 & 1.3 & 0.1 & 0.7 \\
\hline 18:0 & 2.8 & 1.4 & 1.9 & 0.9 & 0.5 & 2.4 & 2.2 & 0.8 & 4.9 & 0.7 & 2.6 \\
\hline
\end{tabular}


N. Gerasimenko et al.

\begin{tabular}{|c|c|c|c|c|c|c|c|c|c|c|c|}
\hline \multicolumn{12}{|l|}{ Continued } \\
\hline $18: 1 n-7$ & 0.2 & & & 0.8 & 0.1 & 0.1 & 0.5 & 0.7 & 0.6 & 0.2 & 0.4 \\
\hline $18: 1 n-9$ & 6.8 & 15.1 & 6.3 & 12.9 & 12.4 & 11.8 & 21.3 & 19.0 & 10.2 & 19.2 & 17.8 \\
\hline $18: 2 n-6(L A)$ & 11.7 & 11.8 & 10.3 & 9.6 & 10.1 & 8.3 & 5.5 & 4.1 & 14.1 & 13.1 & 7.4 \\
\hline $18: 3 n-3($ ALA) & 2.1 & 10.1 & 2.2 & 4.7 & 11.9 & 9.4 & 6.3 & 6.8 & 6.5 & 5.0 & 5.2 \\
\hline $18: 3 n-6$ & 15.0 & 6.9 & 3.0 & 1.3 & 3,6 & 2.4 & 3.0 & 3.5 & 1.3 & 1.2 & 2.2 \\
\hline $18: 4 n-3$ & 10.4 & 5.1 & 10.5 & 6.3 & 9.0 & 8.7 & 5.4 & 4.9 & 11.9 & 10.8 & 4.5 \\
\hline $20: 0$ & 0.2 & 1.2 & & 0.9 & 0.1 & 0.2 & & 0.9 & 0.8 & & 2.3 \\
\hline $20: 4 n-6(\mathrm{AA})$ & 5.9 & 2.1 & 14.6 & 3.4 & 5.3 & 6.2 & 2.7 & 2.8 & 7.0 & 3.6 & 5.8 \\
\hline $20: 5 n-3(E P A)$ & 13.1 & 3.1 & 13.9 & 2.1 & 3.9 & 5.1 & 5.1 & 3.1 & 12.3 & 9.5 & 6.3 \\
\hline$\sum \mathrm{SFA}$ & 21.2 & 43.3 & 31.7 & 37.0 & 43.0 & 39.8 & 47.0 & 37.1 & 33.5 & 35.3 & 47.5 \\
\hline$\sum$ MUFA & 20.6 & 17.6 & 13.8 & 35.6 & 13.2 & 20.1 & 25.0 & 37.7 & 13.4 & 21.5 & 21.1 \\
\hline$\sum$ PUFA & 58.2 & 39.1 & 54.5 & 27.4 & 43.8 & 40.1 & 28.0 & 25.2 & 53.1 & 43.2 & 31.4 \\
\hline$\sum n-6$ PUFA & 32.6 & 20.8 & 27.9 & 14.3 & 19.0 & 16.9 & 11.2 & 10.4 & 22.4 & 17.7 & 15.4 \\
\hline$\sum \mathrm{n}-3$ PUFA & 25.6 & 18.3 & 26.6 & 13.1 & 24.8 & 23.2 & 16.8 & 14.8 & 30.7 & 25.3 & 16.0 \\
\hline$n-6 / n-3$ & 1.27 & 1.14 & 1.03 & 1.09 & 0.77 & 0.73 & 0.67 & 0.70 & 0.73 & 0.69 & 0.96 \\
\hline $\mathrm{LA}+\mathrm{AA} / \mathrm{ALA}+\mathrm{EPA}$ & 1.15 & 1.05 & 1.54 & 1.91 & 0.97 & 1.0 & 0.72 & 0.70 & 1.12 & 1.15 & 1.15 \\
\hline \multirow{3}{*}{ FAs } & \multicolumn{11}{|c|}{ SQDG } \\
\hline & \multicolumn{8}{|c|}{ S. cichorioides } & \multicolumn{3}{|c|}{ F. evanescens } \\
\hline & \multicolumn{3}{|c|}{ Jul } & \multicolumn{2}{|r|}{ Aug } & \multicolumn{3}{|c|}{ Nov } & \multicolumn{3}{|c|}{ Nov } \\
\hline $14: 0$ & \multicolumn{3}{|c|}{4.9} & \multicolumn{2}{|r|}{7.4} & \multicolumn{3}{|c|}{3.4} & \multicolumn{3}{|c|}{19.2} \\
\hline $15: 0$ & & 0.5 & & \multicolumn{2}{|r|}{0.7} & & & & \multicolumn{3}{|c|}{1.2} \\
\hline $16: 0$ & & 54.2 & & \multicolumn{2}{|r|}{63.4} & \multicolumn{3}{|c|}{49.5} & \multicolumn{3}{|c|}{48.0} \\
\hline $16: 1 n-7$ & & 6.9 & & \multicolumn{2}{|r|}{7.5} & \multicolumn{3}{|c|}{7.8} & \multicolumn{3}{|c|}{2.2} \\
\hline $18: 0$ & & 1.5 & & \multicolumn{2}{|r|}{1.3} & \multicolumn{3}{|c|}{4.3} & & 0.3 & \\
\hline $18: 1 \mathrm{n}-7$ & & 0.5 & & & 0.4 & & & & & 0.5 & \\
\hline $18: 1 n-9$ & & 19.5 & & & 16.3 & & 12.8 & & & 17.4 & \\
\hline $18: 2 n-6(L A)$ & & 6.4 & & & 2.6 & & 7.7 & & & 3.7 & \\
\hline $18: 3 n-3($ ALA) & & 1.3 & & & 0.2 & & 2.7 & & & 4.9 & \\
\hline $18: 3 n-6$ & & 1.3 & & & 0.1 & & 4.7 & & & & \\
\hline $18: 4 n-3$ & & 0.4 & & & & & & & & 0.1 & \\
\hline $20: 0$ & & 1.0 & & & 0.1 & & & & & 1.0 & \\
\hline $20: 4 n-6(\mathrm{AA})$ & & 0.6 & & & & & 4.5 & & & 0.9 & \\
\hline $20: 5 n-3(E P A)$ & & 1.0 & & & & & 2.6 & & & 0.6 & \\
\hline$\sum$ SFA & & 62.1 & & & 72.9 & & 57.2 & & & 69.7 & \\
\hline$\sum$ MUFA & & 26.9 & & & 24.2 & & 20.6 & & & 20.1 & \\
\hline$\sum$ PUFA & & 11.0 & & & 2.9 & & 22.2 & & & 10.2 & \\
\hline$\sum n-6$ PUFA & & 8.3 & & & 2.7 & & 16.9 & & & 4.6 & \\
\hline$\sum \mathrm{n}-3$ PUFA & & 2.7 & & & 0.2 & & 5.3 & & & 5.6 & \\
\hline$n-6 / n-3$ & & 3.07 & & & 13.5 & & 3.18 & & & 0.82 & \\
\hline $\mathrm{LA}+\mathrm{AA} / \mathrm{ALA}+\mathrm{EPA}$ & & 3.04 & & & 13.0 & & 2.3 & & & 0.84 & \\
\hline
\end{tabular}

low activity from algae of $S$. cichorioides and $C$. costata had high percentages of SFA and MUFA. MGDG $S$. cichorioides that was collected in August contained only about 2\% PUFA namely $n-6$ PUFA and activity this MGDG was very low (Figure 3). MGDG from alga collected in July as well as MGDG C. costata contained little $n-6$ PUFA and very little $n-3$ PUFA and they were slightly more active, than the MGDG of August of algae. 
At the same time, in MGDG November algae had many PUFA, and among them $\mathrm{n}-6$ PUFA were prevailed. This MGDG stronger than others in third group inhibited ROS. In this group of algae, $n-6 / n-3$ ratio was 0 3.96 and LA + AA/ALA + EPA ratio was 0 - 4.25.

In most cases, MGDG larger inhibit of ROS, than DGDG (Figure 3). In DGDG of all the algae had a lot SFA. In DGDG of the first group with low level of ROS inhibition had a lot of 18:2n-6, but 20:4n- 6 was less and the content of 18:3n-3 and 20:5n - 3 was varied in a wide range. Portion $n-6$ PUFA was high or they predominated in PUFA DGDG. In general, the ratio of $n-6 / n-3$ ranged from 0.69 to 1.27 , but ratio LA + AA/ALA + EPA was greater than or equal to 1 (Table 3). DGDG S. cichorioides also showed differences in the composition of the FAs depending on the months of collecting the alga. Content 18:2n-6 was close in different months, and the contents of 20:4n-6,18:3n-3,18:4n-3, 20:5n-3 varies considerably. At the same time, the ratios of $n-6 / n-3$ and LA + AA/ALA + EPA are slightly different (Table 3). In DGDG second group algae predominated of $n-3$ PUFA. The ratio $n-6 / n-3$ was lower, than in the DGDG algae the first group and was $0.67-0.73$. The ratio LA + AA/ALA + EPA was also smaller than in the first group. DGDG from $D$. divaricata collected in July and September had close amounts of both $n-3$ PUFA and $n-6$ PUFA. However, $n-$ 3 PUFA predominated in both months. The ratio $n-6 / n-3$ and LA + AA/ALA + EPA in DGDG of these algae were very close (Table 3).

SQDG inhibit ROS weakly. SQDG S. cichorioides had high levels of SFA and MUFA and small amount of PUFA in boths month of collecting algae (Table 3). In PUFA SQDG S. cichorioides was greater $\mathrm{n}-6$ PUFA, and in SQDG of $F$. evanescens the content $n-6$ and $n-3$ PUFA were pretty close.

As can be seen, GLs of these algae demonstrated differences in the ratio of FAs. In general, the species of algae, the month of their collection, FAs of lipids, and polar heads of GLs affected the ability to suppress ROS.

\section{Conclusions}

All investigated in this work, extracts of different species of Ochrophyta from the Sea of Japan incorporate significant amounts of GLs and carotenoids. Extracts of algae as well as their MGDG, DGDG, SQDG and fucoxanthin suppresses ROS in LPS-stimulated RAW 264.7 macrophage cells. The degree of inhibition of ROS depends on the species of algae, the month of their collection, the amounts of PUFA, the ratios of $n-3$ and $n-6$ PUFA in the extracts and in GLs, and structures of polar heads of GLs. Obviously, GLs and fucoxanthin are responsible for anti-inflammatory activity and the brown algae can be considered as potential source of the effective anti-inflammatory agents. This preliminary study has shown the prospects of a deeper study of the suppression of ROS with the help of lipids of algae.

Our early studies of the biological activities of lipids and PSP of E. fistulosa, F. evanescens, and S. cichorioides [35]-[37] showed prospect of continuing studies of brown algae. Although there are many publications about anti-inflammatory action of algae extracts and their components from different regions of World Ocean, there is no information about anti-inflammatory properties for species of algae Russian coasts Pacific Ocean. It is necessary the broader screening of algae extracts and their substances on their capability to suppress ROS because this may give for pharmacological industry more perspective species of algae.

\section{Acknowledgements}

The authors would like to thank of skin-divers and workers of Marine Station of the Pacific Institute of Bioorganic Chemistry for technical assistance in collecting seaweeds. We also thank O. Moiseenko for the assistance in the mass spectrometry. This research was supported by Grant of RSCF No. 14-25-00037, Russian Federation.

\section{Conflicts of Interest}

The authors declare no conflict of interest.

\section{References}

[1] Romay, C., Armesto, J., Remirez, D., González, R., Ledon, N. and García, I. (1998) Antioxidant and Anti-Inflammatory Properties of C-Phycocyanin from Blue-Green Algae. Inflammation Research, 47, 36-41. http://dx.doi.org/10.1007/s000110050256

[2] Ruberto, G., Baratta, M.T., Biondi, D.M. and Amico, V. (2001) Antioxidant Activity of Extracts of the Marine Algal 
Genus Cystoseira in a Micellar Model System. Journal of Applied Phycology, 13, 403-407. http://dx.doi.org/10.1023/A:1011972230477

[3] Tierney, M.S., Croft, A.K. and Hayes, M. (2010) A Review of Antihypertensive and Antioxidant Activities in Macroalgae. Botanica Marina, 53, 387-408. http://dx.doi.org/10.1515/bot.2010.044

[4] Sachindra, N.M., Airanthi, M.K.W.A., Hosokawa, M, and Miyashita, K. (2010) Radical Scavenging and Singlet Oxygen Quenching Activity of Extracts from Indian Seaweeds. Journal Food Science Technollogy, 47, 94-99. http://dx.doi.org/10.1007/s13197-010-0022-4

[5] Boonchum, W., Peerapornpisal, Y., Kanjanapothi, D., Pekkoh, J., Pumas, C., Jamjai, U., Amornlerdpison, D., Noiraksar, T. and Vacharapiyasophon, P. (2011) Antioxidant Activity of Some Seaweed from the Gulf of Thailand. International Journal Agriculture and Biology, 13, 95-99.

[6] Kelman, D., Posner, E.K., McDermid, K.J., Tabandera, N.K., Wright, P.R. and Wright, A.D. (2012) Antioxidant Activity of Hawaiian Marine Algae. Marine Drugs, 10, 403-416. http://dx.doi.org/10.3390/md10020403

[7] Siqueira, R.C.L., da Silva, M.S.J., de Alencar, D.B., Pires, A.F., de Alencar, N.M.N., Pereira, M.G., Cavada, B.S., Sampaio, A.H., Farias, W.R.L. and Assreuy, A.M.S. (2011) In vivo Anti-inflammatory Effect of a Sulfated Polysaccharide Isolated from the Marine Brown Algae Lobophoravariegata. Pharmaceutical Biology, 49, 167-174. http://dx.doi.org/10.3109/13880209.2010.505605

[8] Vo, T.S., Ngo, D.H. and Kim, S.K. (2012) Potential Targets for Anti-Inflammatory and Anti-Allergic Activities of Marine Algae: an Overview. Inflammation Allergy Drug Targets, 11, 90-101. http://dx.doi.org/10.2174/187152812800392797

[9] Dore, C.M.P.G., Alves, M.G.C.F., Costa, T.G., Sabry, D.A., Rego, L.A.S., Accado, C.M., Rocha, H.A.O., Filgueira, L.G.A. and Leite, E.L. (2013) A Sulfated Polysaccharide, Fucan, Isolated from Brown Algae Sargassum vulgare with Anticoagulant, Antithrombotic, Antioxidant and Anti-Inflammatory Effects. Carbohydrate Polymers, 91, 467-475. http://dx.doi.org/10.1016/j.carbpol.2012.07.075

[10] Samarakoon, K. and Jeon, Y.J. (2012) Bio-Functionalities of Proteins Derived from Marine Algae: A Review. Food Research International, 48, 948-960. http://dx.doi.org/10.1016/j.foodres.2012.03.013

[11] Vo, T.S., Ngo, D.H. and Kim, S.K. (2012) Marine Algae as a Potential Pharmaceutical Source for Anti-Allergic Therapeutics. Process Biochemistry, 47, 386-394. http://dx.doi.org/10.1016/j.procbio.2011.12.014

[12] Pangestuti, R. and Kim, S.K. (2011) Neuroprotective Effects of Marine Algae. Marine Drugs, 9, 803-818. http://dx.doi.org/10.3390/md9050803

[13] Waris, G. and Ahsan, H. (2006) Reactive Oxygen Species: Role in the Development of Cancer and Various Chronic Conditions. Journal of Carcinogenesis, 5, 14. http://dx.doi.org/10.1186/1477-3163-5-14

[14] Beaglehole, R.S., Reddy, E.S., Voute, J. and Leeder, S. (2007) Prevention of Chronic Diseases: A Call to Action. The Lancet, 370, 2152-2157. http://dx.doi.org/10.1016/S0140-6736(07)61700-0

[15] Abad, M.J., Bedoya, L.M. and Bermejo, P. (2008) Natural Marine Anti-Inflammatory Products. Medicinal Chemistry, 8, 740-754. http://dx.doi.org/10.2174/138955708784912148

[16] Wang, W., Wang, S.X. and Guan, H.S. (2012) The Antiviral Activities and Mechanisms of Marine Polysaccharides: An Overview. Marine Drugs, 10, 2795-2816. http://dx.doi.org/10.3390/md10122795

[17] D’Orazio, N., Gammone, M.A., Gemello, E., De Girolamo, M., Cusenza, S. and Riccioni, G. (2012) Marine Bioactives: Pharmacological Properties and Potential Applications against Inflammatory Diseases. Marine Drugs, 10, 812-833. http://dx.doi.org/10.3390/md10040812

[18] Kang, H.S., Chung, H.Y., Kim, J.Y., Son, B.W., Jung, H.A. and Choi, J.S. (2004) Inhibitory Phlorotannins from the Edible Brown Alga Ecklonia stolonifera on Total Reactive Oxygen Species (ROS) Generation. Archives of Pharmacal Research, 27, 194-198. http://dx.doi.org/10.1007/BF02980106

[19] Kim, Y.A., Kong, C.S., Um, Y.R., Lee, J.I., Nam, T.J. and Seo, Y.W. (2008) Antioxidant Efficacy of Extracts from a Variety of Seaweeds in a Cellular System. Ocean Science Journal, 43, 31-37. http://dx.doi.org/10.1007/BF03022429

[20] Badrinathan, S., Suneeva, S.C., Shiju, T.M., Girish Kumar, C.P. and Pragasam, V. (2011) Exploration of a Novel Hydroxyl Radical Scavenger from Sargassum myriocystum. Journal of Medical Plants Research, 5, 1997-2005.

[21] Jung, H.A., Jin, S.E., Ahn, B.R., Lee, C.M. and Choi, J.S. (2013) Anti-inflammatory Activity of Edible Brown Alga Eiseniabicyclis and Its Constituents Fucosterol and Phlorotannins in LPS-stimulated RAW264.7 Macrophages. Food and Chemistry Toxicology, 59, 199-206. http://dx.doi.org/10.1016/j.fct.2013.05.061

[22] Islam, M.N., Ishita, I.J., Jin, S.E., Choi, R.J., Lee, C.M., Kim, Y.S., Jung, H.A. and Choi, J.S. (2013) Anti-Inflammatory Activity of Edible Brown Alga Saccharina japonica and Its Constituents Pheophorbide $a$ and Pheophytin $a$ in LPS-Stimulated RAW 264.7 Macrophage Cells. Food and Chemistry Toxicology, 55, 541-548. http://dx.doi.org/10.1016/j.fct.2013.01.054 
[23] McCauley, J.I., Meyer, B.J., Winberg, P.C., Ranson, M. and Skropeta, D. (2015) Selecting Australian Marine Macroalgae Based on the Fatty Acid Composition and Anti-Inflammatory Activity. Journal of Applied Phycology, 27, 2111-2121. http://dx.doi.org/10.1007/s10811-014-0465-5

[24] Júnior, S.Q., Carneiro, V.H.A., Fontenelle, T.P.C., Chaves, L.D.S., Mesquita, J.X., de Brito, T.V., Siva Prudêncio, R., de Oliveira, J.S., Medeiros, J.-V.R., Aragão, K.S., Ribeiro, R.D.A., Barbosa, A.L.D.R. and Freitas, A.L.P. (2015) Antioxidant and Anti-Inflammatory Activities of Methanol Extractand Its Fractions from the Brown Seaweed Spatoglossum schroederi. Journal of Applied Phycology, 27, 2367-2376. http://dx.doi.org/10.1007/s10811-014-0497-x

[25] Kim, M.M. and Kim, S.K. (2010) Effect of Phloroglucinol on Oxidative Stress and Inflammation. Food and Chemistry Toxicology, 48, 2925-2933. http://dx.doi.org/10.1016/j.fct.2010.07.029

[26] Kim, S.K. and Himaya, S.W. (2011) Medicinal Effects of Phlorotannins from Marine Brown Algae. Advances in Food Nutrition Research, 64, 97-109. http://dx.doi.org/10.1016/B978-0-12-387669-0.00008-9

[27] Kim, S.J., Kim, E.A., Kang, M.C., Lee, J.H., Yang, H.W., Lee, J.S., Lim, T.I. and Jeon, Y.J. (2014) Polyphenol-Rich Fraction from Ecklonia cava (a Brown Alga) Processing By-Product Reduces LPS-Induced Inflammation in Vitro and in Vivo in a Zebrafish Model. Algae, 29, 165-174. http://dx.doi.org/10.4490/algae.2014.29.2.165

[28] Shiratori, K., Ohgami. K., Ilieva, I., Jin, X.-H., Koyama, Y., Miyashita, K., Yoshida, K., Kase, S. and Ohno, S. (2005) Effects of Fucoxanthin on Lipopolysaccharide-induced Inflammation in Vitro and in Vivo. Experimental Eye Research, 81, 422-428. http://dx.doi.org/10.1016/j.exer.2005.03.002

[29] Heo, S.J., Yoon, W.J., Kim, K.N., Ahn, G.N., Kang, S.M., Kang, D.H., Affan, A., Oh, C., Jung, W.K. and Jeon, Y.J. (2010) Evaluation of Anti-Inflammatory Effect of Fucoxanthin Isolated from Brown Algae in LipopolysaccharideStimulated RAW 264.7 Macrophages. Food and Chemistry Toxicology, 48, 2045-2051. http://dx.doi.org/10.1016/j.fct.2010.05.003

[30] Zou, Y., Li, Y., Kim, M.-M., Lee, S.-H. and Kim, S.-K. (2009) Ishigoside, a New Glyceroglycolipid Isolated from the Brown Alga Ishige okamurae. Biotechnology and Bioprocess Engineering, 14, 20-26. http://dx.doi.org/10.1007/s12257-008-0131-3

[31] Banskota, A.H., Stefanova, R., Sperker, S., Lall, S.P., Craigie, J.S. and Hafting, J.T. (2014a) Lipids Isolated from the Red Alga Chondrus crispus Inhibit Nitric Oxide Production. Journal of Applied Phycology, 26, 1565-1571. http://dx.doi.org/10.1007/s10811-013-0174-5

[32] Banskota, A.H., Stefanova, R., Sperker, S., Lall, S.P., Craigie, J.S., Hafting, J.T. and Critchley, A.T. (2014b) Polar Lipids from the Marine Macroalga Palmaria palmate Inhibit Lipopolysaccharide-Induced Nitric Oxide Production in RAW 264.7 Macrophage Cells. Phytochemistry, 101, 101-108. http://dx.doi.org/10.1016/j.phytochem.2014.02.004

[33] Lopes, G., Daletos, G., Proksch, P., Andrade, P.B. and Valentão, P. (2014) Anti-Inflammatory Potential of Monogalactosyl Diacylglycerols and a Monoacylglycerol from the Edible Brown Seaweed Fucus spiralis Linnaeus. Marine Drugs, 12, 1406-1418. http://dx.doi.org/10.3390/md12031406

[34] Robertson, R.C., Guiheneuf, F., Bahar, B., Schmid, M., Stengel, D.B., Fitzgerald, G.F., Ross, R.P. and Stanton, C. (2015) The Anti-Inflammatory Effect of Algae-Derived Lipid Extracts on Lipopolysaccharide (LPS)-Stimulated Human THP-1 Macrophages. Marine Drugs, 13, 5402-5424. http://dx.doi.org/10.3390/md13085402

[35] Gerasimenko, N.I., Martyyas, E.A. and Busarova, N.G. (2012) Composition of Lipids and Biological Activity of Lipids and Photosynthetic Pigments from Algae of the Families Laminariaceae and Alariaceae. Chemistry of Natural Compounds, 48, 737-741. http://dx.doi.org/10.1007/s10600-012-0371-5

[36] Gerasimenko, N.I., Busarova, N.G. and Martyyas, E.A. (2012) Composition of Lipids from Fucusevanescens (Sea of Okhotsk and Japan) and Biological Activity of Lipids and Photosynthetic Pigments. Chemistry of Natural Compounds, 48, 742-747. http://dx.doi.org/10.1007/s10600-012-0372-4

[37] Martyyas, E.A., Gerasimenko, N.I., Busarova, N.G., Yurchenko, E.A., Skriptsova, A.V. and Anisimov, M.M. (2013) Seasonal Changes in Biological Activity of Lipids and Photosynthetic Pigments of Saccharinacichorioides (Miyabe) (Laminariaceae Family). Russian Journal of Bioorganic Chemistry, 39, 720-727. http://dx.doi.org/10.1134/S106816201307008X

[38] Pollet, S., Ermidou, S., Le Saux, F., Monge, M. and Baumnn, N. (1978) Microanalysis of Brain Lipids: Multiple Two-Dimensional Thin-Layer Chromatography. Journal of Lipid Research, 19, 916-921.

[39] Vaskovsky, V.E., Kostetsky, E.Y. and Vasendin, I.M. (1975) A Universal Reagent for Phospholipid Analysis. Journal of Chromatography, 114, 129-141. http://dx.doi.org/10.1016/S0021-9673(00)85249-8

[40] Radwan, S.S. (1978) Coupling of Two-Dimensional Thin Layer Chromatography with Gas Chromatography for Quantitative Analysis of Lipid Classes and Their Constituent Fatty Acid. Journal Chromatographic Science, 16, 538-542. http://dx.doi.org/10.1093/chromsci/16.11.538

[41] Whitlle, S.J. and Casselton, P.J. (1975) The Chloroplast Pigments of the Algal Classes Eustigmatophyceae and Xanthophyceae. I. Eustigmatophyceae. British Phycological Journal, 10, 179-191.

http://dx.doi.org/10.1080/00071617500650171 
[42] Lichtenthaler, H.K. (1987) Chlorophylls and Carotenoids: Pigments of Photosynthetic Biomembranes. Methods in Enzymology, 148, 350-382. http://dx.doi.org/10.1016/0076-6879(87)48036-1

[43] Hashimoto, T., Ozaki, Y., Taminato, M., Das, S.K., Mizimo, M., Yoshimura, K., Maoka, T. and Kanozawa, K. (2009) The Distribution and Accumulation of Fucoxanthin and Its Metabolites after Oral Administration in Mice. British Journal Nutrition, 102, 242-248. http://dx.doi.org/10.1017/S0007114508199007

[44] Prevot, A.F. and Mordret, F.X. (1976) Utilisation des Colonnes Capillaries de Verre Pour l'Analyse des Corps Gras par Chromatographie en Phase Gazeuse. Revue Francaise des Corps Gras, 23, 409-423.

[45] Strànsky, K., Jursík, T. and Vitek, A. (1997) Standard Equivalent Chain Length Values of Monoenic and Polyenic (Methylene Interrupted) Fatty Acids. Journal of High Resolution Chromatography, 20, 143-158. http://dx.doi.org/10.1002/jhrc.1240200305

[46] Rasoarahona, J.R.E. and Ramanoelina, P.A.R. (2008) Muscle Lipids and Fatty Acid Profiles of the Sea Catfish (Arius madagascariensis) in Madagascar Inland Waters. Journal of the American Oil Chemists Society, 85, 435-440. http://dx.doi.org/10.1007/s11746-008-1211-4

[47] Tada, H., Shiho, O., Kuroshima, K., Koyama, M. and Tsukamoto, K. (1986) An Improved Colorimetric Assay for Interleukin 2. Journal of Immunological Methods, 93, 157-165. http://dx.doi.org/10.1016/0022-1759(86)90183-3

[48] Kicha, A.A., Kalinovsky, A.I., Malyarenko, T.V., Ivanchina, N.V., Dmitrenok, P.S., Menchinskaya, E.S., Yurchenko, E.A., Pislyagin, E.A., Aminin, D.L., Huong, T.T., Long, P.Q. and Stonik, V.A. (2015) Cyclic Steroid Glycosides from the Starfish Echinaster luzonicus: Structures and Immunomodulatory Activities. Journal of Natural Products, 78, 1397-1405. http://dx.doi.org/10.1021/acs.jnatprod.5b00332

[49] Khotimchenko, S.V. (2002) Distribution of Glyceroglycolipids in Marine Algae and Grasses. Chemistry of Natural Compounds, 38, 223-229. http://dx.doi.org/10.1023/A:1020471709232

[50] Guschina, I.A. and Harwood, J.L. (2009) Algal Lipids and Effect of the Environment on Their Biochemistry. In: Arts, M.T., Brett, M.T., and Kainz, M., Eds., Lipids in Aquatic Ecosystems, Springer Science, Business Media LLC, 1-24. http://dx.doi.org/10.1007/978-0-387-89366-2 1

[51] Miyashita, K., Nishikawa, S., Beppu, F., Tsukui, T., Abea, M. and Hosokawa, M. (2011) The Allenic Carotenoid Fucoxanthin, a Novel Marine Nutraceutical from Brown Seaweeds. Journal of the Science of Food and Agriculture, 91, 1166-1174. http://dx.doi.org/10.1002/jsfa.4353

[52] Funga, A., Hamida, N. and Lua, J. (2013) Fucoxanthin Content and Antioxidant Properties of Undaria pinnatifida. Food Chemistry, 136, 1055-1062. http://dx.doi.org/10.1016/j.foodchem.2012.09.024

[53] Mikami, K. and Hosokawa, M. (2013) Biosynthetic Pathway and Health Benefits of Fucoxanthin, an Algae-Specific Xanthophyll in Brown Seaweeds. International Journal of Molecular Science, 14, 13763-13781. http://dx.doi.org/10.3390/ijms140713763

[54] Kanda, H., Kamo, Y., Machmudah, S., Goto, W. and Goto, M. (2014) Extraction of Fucoxanthin from Raw Macroalgae Excluding Drying and Cell Wall Disruption by Liquefied Dimethyl Ether. Marine Drugs, 12, 2383-2396. http://dx.doi.org/10.3390/md12052383

[55] Bruno, A., Rossi, C., Marcolongo, G., Di Lena, A., Venzo, A., Berrie, C.P. and Corda, D. (2005) Selective in Vivo Anti-Inflammatory Action of the Galactolipid Monogalactosyldiacylglycerol. European Journal of Pharmacology, 524, 159-168. http://dx.doi.org/10.1016/j.ejphar.2005.09.023

[56] Simopoulos, A.P. (2002) Omega-3 Fatty Acids in Inflammation and Autoimmune Diseases. The Journal of the American Colllege of Nutrrition, 21, 495-505. http://dx.doi.org/10.1080/07315724.2002.10719248

[57] Simopoulos, A.P. (2008) The Importance of the Omega-6/Omega-3 Fatty Acid Ratio in Cardiovascular Disease and Other Chronic Diseases. Experimental Biology and Medicine, 233, 674-688. http://dx.doi.org/10.3181/0711-MR-311

[58] Khan, M.N.A., Cho, J.Y., Lee, M.C., Kang, J.Y., Park, N.G., Fujii, H. and Hong, Y.K. (2007) Isolation of Two Anti-Inflammatory and One Pro-Inflammatory Polyunsaturated Fatty Acids from the Brown Seaweed Undaria pinnatifida. Journal of Agricultural and Food Chemistry, 55, 6984-6988. http://dx.doi.org/10.1021/jf071791s

[59] Calder, P.C. (2011) Fatty Acids and Inflammation: The Cutting Edge between Food and Pharma. European Journal of Pharmacology, 668, S50-S58. http://dx.doi.org/10.1016/j.ejphar.2011.05.085

[60] Glick, N.R. and Fisher, M.H. (2013) The Role of Essential Fatty Acids in Human Health. Journal of Evidence-Based Complementary and Alternative Medicine, 18, 268-289. http://dx.doi.org/10.1177/2156587213488788

[61] Banskota, A.H., Stefanova, R., Gallant, P. and McGinn, P.J. (2013a) Mono- and Digalactosyl Diacylglycerols: Potent Nitric Oxide Inhibitors from the Marine Microalga Nannochloropsis granulate. Journal of Applied Phycology, 25, 349357. http://dx.doi.org/10.1007/s10811-012-9869-2

[62] Banskota, A.H., Gallant, P., Stefanova, R., Melanson, R. and O’Leary, S.J.B. (2013) Monogalactosyldiacylglycerols, Potent Nitric Oxide Inhibitors from the Marine Microalga Tetraselmis chui. Natural Products Research, 27, 10841090. http://dx.doi.org/10.1080/14786419.2012.717285 


\section{Submit or recommend next manuscript to SCIRP and we will provide best service for you:}

Accepting pre-submission inquiries through Email, Facebook, Linkedin, Twitter, etc A wide selection of journals (inclusive of 9 subjects, more than 200 journals)

Providing a 24-hour high-quality service

User-friendly online submission system

Fair and swift peer-review system

Efficient typesetting and proofreading procedure

Display of the result of downloads and visits, as well as the number of cited articles

Maximum dissemination of your research work

Submit your manuscript at: http://papersubmission.scirp.org/ 